Connecticut College

Digital Commons @ Connecticut College

$10-1-2018$

\title{
Factors Affecting Gastropod Larval Development and Performance: A Systematic Review
}

\author{
Maria Rosa \\ Connecticut College, maria.rosa@conncoll.edu \\ Dianna K. Padilla \\ SUNY Stony Brook \\ David Charifson \\ SUNY Stony $b$ \\ Alyssa Liguori \\ SUNY Stony Brook \\ Mica McCarty-Glenn \\ SUNY Stony Brook \\ See next page for additional authors
}

Follow this and additional works at: https://digitalcommons.conncoll.edu/biofacpub

Part of the Animal Experimentation and Research Commons, and the Marine Biology Commons

\section{Recommended Citation}

Rosa, Maria; Padilla, Dianna K.; Charifson, David; Liguori, Alyssa; McCarty-Glenn, Mica; and Rugila, Allison, "Factors Affecting Gastropod Larval Development and Performance: A Systematic Review" (2018).

Biology Faculty Publications. 36.

https://digitalcommons.conncoll.edu/biofacpub/36

This Article is brought to you for free and open access by the Biology Department at Digital Commons @ Connecticut College. It has been accepted for inclusion in Biology Faculty Publications by an authorized administrator of Digital Commons @ Connecticut College. For more information, please contact bpancier@conncoll.edu.

The views expressed in this paper are solely those of the author. 


\section{Authors}

Maria Rosa, Dianna K. Padilla, David Charifson, Alyssa Liguori, Mica McCarty-Glenn, and Allison Rugila 


\title{
FACTORS AFFECTING GASTROPOD LARVAL DEVELOPMENT AND PERFORMANCE: A SYSTEMATIC REVIEW
}

\author{
DIANNA K. PADILLA, ${ }^{\dagger \dagger}$ DAVID CHARIFSON, ALYSSA LIGUORI, MICA MCCARTY-GLENN, \\ MARIA ROSA AND ALLISON RUGILA \\ Department of Ecology and Evolution, Stony Brook University, 650 Life Sciences, Stony Brook, NY \\ $11794-5425$
}

\begin{abstract}
The goal of this article was to use a systematic review of studies on the larval stages of gastropods reared to metamorphosis to determine whether there are general patterns for the effects of temperature, rearing density, and food availability on larval development and performance among species, major taxa, and modes of development. Most studies did not include sufficient metadata to be included in many of the analyses. For all analyses, there were differences among major groups of taxa in terms of response to the considered variables. Increased temperature was frequently correlated with decreased development time and increased growth but often not for the same taxa. Increased larval density was generally correlated with increased development time, but again, the patterns were not consistent across taxa. The most consistent pattern was the positive correlation between per capita food availability and larval growth. In all but two cases, patterns for the most studied species, Crepidula fornicata, were opposite those of other caenogastropods. This indicates that caution should be used when drawing general patterns among species based on studies of $C$. fornicata. Among lecithotrophs, the vetigastropod Haliotis rufescens was the most studied. In this case, patterns found for this species were similar to those for all other vetigastropods; however, few species outside the genus Haliotis have been studied. Increased temperature was associated with reduced survivorship and, in the most studied clade, the Vetigastropoda, reduced time to metamorphosis, which suggests that there may be an energetic cost to more rapid development or physiological mechanisms for coping with heat stress. Curiously, increased larval density was associated with increased survivorship for lecithotrophs. In several cases, however, there were too few studies, or the studies that were found did not provide enough metadata to be included in analyses. Although some patterns emerged from existing research on gastropod larvae, studies on a more diverse set of species that report all metadata are required for cross-study comparisons, which are crucial for drawing robust general conclusions.
\end{abstract}

KEY WORDS: Crepidula fornicata, Haliotis, lecithotrophic development, planktotrophic development, veliger

\section{INTRODUCTION}

For most biological questions of interest, it is important to know the generalizability of studies of individual species; can a study on one species of mollusc, or even one species of gastropod, be generalized to other, similar species? Much biological research presently focuses on a few key model species. Model species are selected for focused study because aspects of their life history, development, or genetic characteristics make them particularly amenable to experiments. In other cases, species are selected for focused study because of economic or other social importance to humans. But, as more information is gained, even greater variation in many traits among and within species has been found. Thus, an understanding of important phylogenetic or evolutionary signatures that appear to drive patterns among species, or correlations between species traits and ecological or environmental conditions, are needed to make the most of the data that exist and to focus future studies.

For studies on biological systems, particularly organismal biology, new information on various aspects of individual species appears continually. As a consequence, the ability to digest this deluge of information poses a great challenge. To date, however, the ability to generalize among species, or to find general principles or patterns, is limited. Ultimately, there is hope that studies of single species, including studies of early life stages of invertebrates, can reveal general principles. For many

\footnotetext{
*Corresponding author. E-mail: dianna.padilla@stonybrook.edu
} $\dagger$ All authors contributed equally to this paper.

DOI: $10.2983 / 035.037 .0414$ important questions in biology, this assumption remains untested.

The first goal of this review was to examine studies on the larval stages of gastropods and determine if there are patterns among species, major taxa, and development modes in terms of the effects of temperature and food availability on development time and survivorship. A second goal was to determine whether overall food concentration, independent of animal density, or per capita food ration had a greater impact on development time, in particular, time to metamorphosis as well as survivorship during the larval phase for species with planktotrophic larvae. These questions are important for understanding potential trade-offs between physiological processes during early life history stages, potential limits on wild populations, and the relative importance of these factors for growing animals in laboratory experiments and for aquaculture. Therefore, a systematic review of the literature on experiments conducted with gastropod larvae was used to determine if patterns could be discerned from existing studies. Systematic reviews are intended to be exhaustive reviews of published literature focused on a particular research question and include literature obtained through repeatable search methods, allowing a synthesis of all high-quality research evidence relevant to the question of interest (Pullin \& Stewart 2006). The methodology used for a systematic review needs to be transparent and repeatable so as to minimize the bias of information included. This approach produces a survey of a very broad range of literature, and not just a focus on literature most familiar to the authors, or only the most recently published studies. 


\section{MATERIALS AND METHODS}

To identify articles suitable for inclusion in this review, a systematic review of the published literature was conducted. First, the literature was searched through a number of webbased literature collections and databases. In all cases, searches included from January 1 of the earliest year available through the Stony Brook University Library collection through December 14, 2016. This included the Web-of-Science Core Collection, which includes Science Citation Index Expanded (1900 to present), Social Sciences Citation Index (1956 to present), Arts and Humanities Citation Index (1975 to present), Conference Proceedings Citation Index: Science (1991 to present), Conference Proceedings Citation Index: Social Science and Humanities (1991 to present), Book Citation Index: Science (2005 to present), Book Citation Index: Social Sciences and Humanities (2005 to present), Emerging Sources Citation Index (2015 to present), Current Chemical Reactions (1985 to present, which also includes Institut National de la Propriete Industriéllé Structure Data back to 1840), and Index Chemicus (1993 to present). Biological Abstracts (1980 to present), BIOSIS Citation IndexSM (1926 to present), Current Contents Connect (1998 to present), Data Citation IndexSM (1900 to present), Derwent Innovations IndexSM (1963 to present), KCI-Korean Journal Database (1980 to present), MEDLINE (1950 to present), Russian Science Citation Index (2005 to present), SciELO Citation Index (1997 to present), and Zoological Record (1864 to present) were also included in the search.

In all cases, the key words gastropod* AND larv* AND experiment NOT Crepidula* NOT parasite were used. Articles on the gastropod genus Crepidula (Lamarck, 1799) were found for a previous project (Padilla et al. 2014) by using the search terms larv* AND experiment AND Crepidula* NOT parasite and were added to the literature discovered through this search. Articles on Crepidula spp. larvae were then searched using the same search terms to find articles published from the end of the previous search (May 31, 2013) through December 16, 2016.

Initial searches yielded 558 citations, seven of which were duplicates, six citations that were not on gastropods or did not include experiments, plus an additional 113 publications on Crepidula for a total of 671 publications. Attempts were made to find experts to translate the articles that were not in English. All but two articles in Korean and one article in Japanese were translated. Publications that focused on embryos in egg cases or masses, or studies that were nonexperimental observations of a few individuals, and studies where animals were not identified to species were not included. After close reading, 126 articles had sufficient data and metadata and were included in this review. Because some studies included multiple experiments and multiple experimental treatments (e.g., different temperatures or food concentrations), each experiment and experimental treatment within each study were considered separately in the review. For each study, the species that was the focus of the study or experiment was determined. The World Register of Marine Species was used to determine current taxonomic status of accepted species and subspecies names as of January 19, 2018.

The following were determined for each species: the developmental mode (whether larvae were planktotrophic, lecithotrophic, facultative planktotrophic, or poecilogonous), major taxonomic clade, geographic range, habitat types (e.g., subtidal or intertidal zone), and trophic type (detritivore, herbivore, predator, scavenger, and suspension feeder). The following were recorded (if reported) for each experiment in each publication: larval density, microalgal food fed for feeding larvae, food concentration, and feeding frequency. Also recorded (if reported) were water change frequency, rearing temperature, time to metamorphosis, time to competence, survivorship, growth rate, and the time over which growth was quantified. In some treatments of some experiments, larvae were starved, and those cases were considered a food density of zero. Studies that reported that larvae were fed ad libitum could not be used when considering the density of food that larvae were fed. For larval competence, only studies that experimentally tested for competence and provided a percentage of larvae that were competent for metamorphosis after a specific number of days were included. For metamorphosis, only studies that reported the time to metamorphosis were included. And, for survivorship, only studies that provided a quantitative assessment of survivorship were included.

Correlations among factors of interest were then tested, including temperature, larval density, food concentration, and per capita food availability.

\section{RESULTS}

A total of 126 publications were included in this review. Experiments with planktotrophic larvae were the focus of 84 publications ( $67 \%$ of all publications) published from 1967 to the present (Fig. 1). For species with lecithotrophic larvae, 46 articles $(37 \%$ of the total) were included. The search results also included seven publications on five species with poecilogony, all of which are in the Heterobranchia clade. For poecilogonous species, experiments and experimental treatments conducted on planktotrophic larvae were considered with those from species with planktotrophic development and larvae with lecithotrophy considered with species that have lecithotrophic development. These species included Alderia modesta (Lovén, 1844) and Alderia willowi (Krug, Ellingson, Burton \& Valdés, 2007) (Seelemann 1967, Krug et al. 2012), which are herbivores, whereas Dendronotus frondosus (Ascanius, 1774) (Sisson 2002), Tenellia adspersa (Nordmann, 1845), and Phestilla sibogae (Bergh, 1905) are predators (Chester 1996). These five species are evenly split between those that are subtidal, intertidal, or both and are mostly from the Atlantic in North America and Europe, but one species is from the Indo-Pacific.

For 38 species, there was only a single publication reporting research on larval development to metamorphosis. Of those 38 , 13 publications included a single experiment with only one treatment. The rest had from 2 to 10 different treatments within one experiment in a publication. The remaining publications included from two to six experiments with up to 28 total different treatment levels in the same publication (Table 1).

By far, the most publications were on species of Crepidula (42 publications) and primarily on Crepidula fornicata (Linnaeus, 1758) (33 publications, 82 different experiments, and 281 cumulative different treatment levels), which has planktotrophic larvae. The second most studied group was the genus Haliotis (37 publications). All species in this genus have lecithotrophic larvae. Twelve different species have been studied, and Haliotis rufescens (Swainson, 1822) has been the focus of most of these studies (12 publications, 18 experiments 


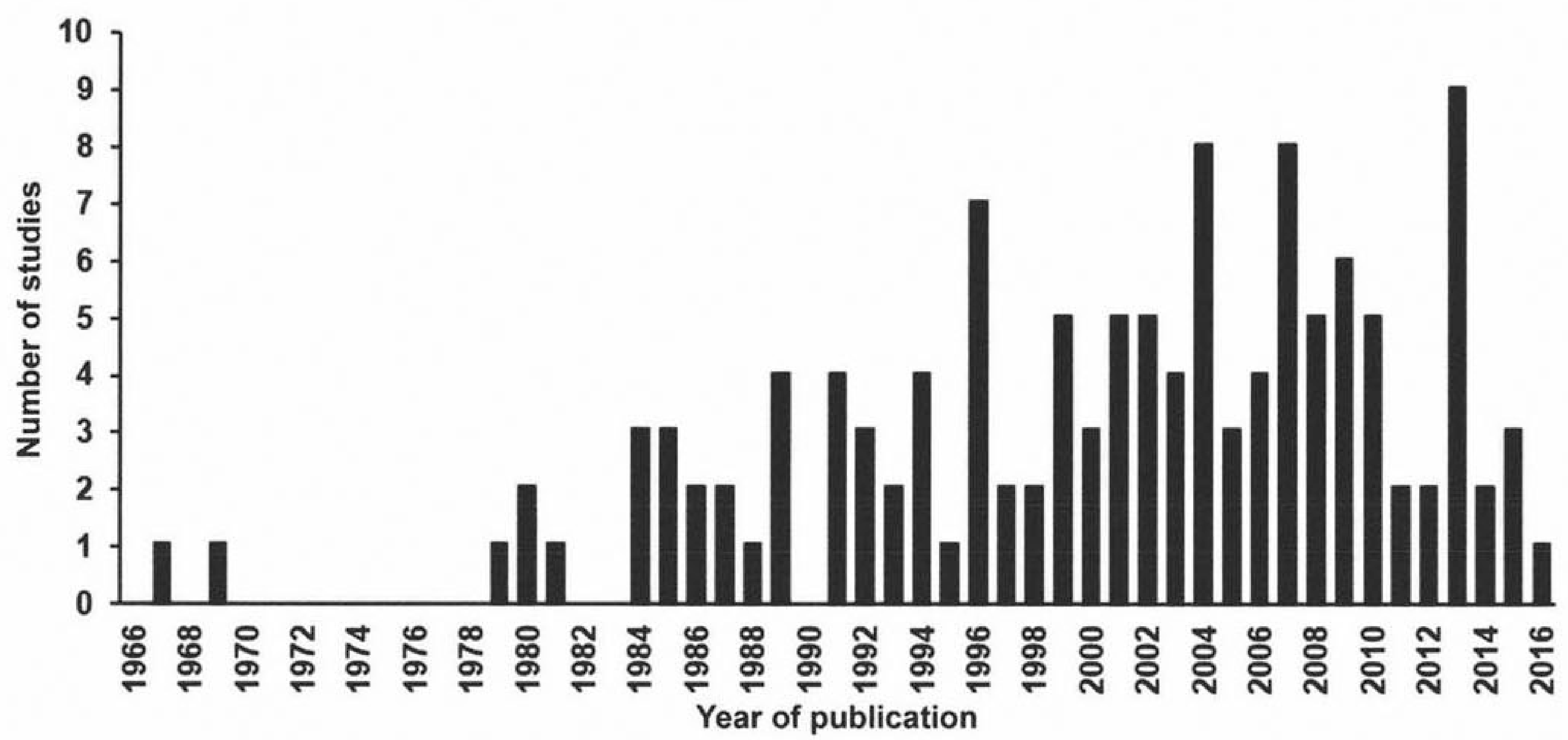

Figure 1. The number of studies on gastropod larvae by year included in this systematic review. The literature from 1840 to December 14,2016 , was reviewed. The first article to fit the criteria of this review was published in 1967.

with a total of 60 different treatments). The species Haliotis diversicolor (Reeve, 1846) and Haliotis iris (Gmelin, 1791) were each the focus of five publications. Studies of $H$. diversicolor included 10 different experiments and 30 different treatment levels and for $H$. iris, there were seven different experiments with 15 different treatments. The third most studied species was Lobatus (Strombus) gigas (Linnaeus, 1758), which has planktotrophic larvae (eight publications, 12 different experiments, and 62 different treatment levels). The remaining species were the focus of from two to five publications, including from 2 to 12 total experiments and 2 to 40 total different treatment levels (Table 1).

\section{Planktotrophic Larvae}

Studies on planktotrophic larvae included 36 currently recognized species within 25 currently recognized genera (Table 1). The larvae of one species, Conus pennaceus (Born, 1778), are reported to be facultative planktotrophs (Perron 1981) and were included with the planktotrophs. Studies with planktotrophic larvae included 28 species of Caenogastropoda, 13 of which are in the Neogastropoda, and eight species of Heterobranchia (Table 1). In terms of trophic roles, two species were detritivores, 11 species were herbivores, 13 were predators, four were scavengers, which may also be predators or detritivores, and six species were suspension feeders.

In terms of the major types of habitats, for species with planktotrophic larvae, including the facultative planktotroph, two species are found in brackish waters, and 15 species live in the intertidal zone, whereas 13 species are primarily found in the subtidal zone. Species that were the targets of study are from a wide range of geographic areas, covering most of the globe, including China, Taiwan, Sea of Japan, Indonesia, Thailand, Russia, Hawaii, North American Pacific coast, North American Atlantic and Gulf Coast, Caribbean, Central and South American Pacific Coast, South American Atlantic coast, the Atlantic coast in Europe, South Africa, Madagascar, the Red Sea, the Indian
Ocean, the Indo-Pacific, New Zealand, and Australia. Literature searches produced only three species with planktotrophic larvae that are currently grown for aquaculture [Strombus pugilis (Linnaeus, 1758), Concholepas concholepas (Bruguiere, 1789), Babylonia areolata (Link, 1807)] and one species that is under consideration for future aquaculture [Dicathais orbita (Gmelin, 1791)].

Sixty-seven percent of the publications included in this review (84) were studies of feeding larvae. This included a total of 182 separate experiments with a total of 645 total treatments. For experiments with feeding larvae, $90 \%$ (163) reported the temperature, $98 \%$ (178) reported the food species that the larvae were fed, $75 \%$ (137) reported the feeding frequency, $78 \%$ (142) reported the food concentration, $92 \%$ (167) reported larval density, $30 \%$ (55) reported the time to competency in larvae, and $32 \%$ (59) reported the time to metamorphosis. Survivorship was reported in $51 \%$ (92) of experiments.

\section{Temperature}

Time to Metamorphosis

Of the 645 experimental treatments with planktotrophic larvae, only $138(21.4 \%)$ reported both temperature and time to metamorphosis. For planktotrophic larvae, overall, there was a significant negative correlation between temperature and time to metamorphosis ( $n=138, P=0.0016, r=-0.266$; Fig. 2 ). With warmer temperature, larvae developed faster. This pattern, however, was driven primarily by Crepidula fornicata, which displayed a strong negative correlation between temperature and time to metamorphosis $(n=47, P=0.036, r=-0.307$; Fig. 2). There was no correlation between temperature and time to metamorphosis for caenogastropods other than $C$. fornicata or neogastropods $(n=48, P=0.168)$, or for just the Neogastropoda $(n=18, P=0.937)$. There was, however, a positive correlation between temperature and time to metamorphosis for the Heterobranchia ( $n=25, P=0.025, r=0.448$; Fig. 2). 
TABLE 1.

Species that were the focus of research included in this review.

\begin{tabular}{|c|c|c|c|c|c|}
\hline $\begin{array}{l}\text { Currently accepted } \\
\text { species name }\end{array}$ & $\begin{array}{c}\text { Species name } \\
\text { as in publication }\end{array}$ & $\begin{array}{c}\text { Developmental } \\
\text { mode }\end{array}$ & Major clade & $\begin{array}{c}\text { No. of } \\
\text { publications }\end{array}$ & $\begin{array}{l}\text { No. of experimental } \\
\text { treatments }\end{array}$ \\
\hline Crepidula fornicata & C. fornicata & Planktotrophic & Caenogastropoda & 33 & 281 \\
\hline Lobatus gigas & Strombus gigas & Planktotrophic & Caenogastropoda & 8 & 62 \\
\hline Ergaea walshi & Crepidula plana & Planktotrophic & Caenogastropoda & 5 & 40 \\
\hline Crepidula onyx & C. onyx & Planktotrophic & Caenogastropoda & 4 & 39 \\
\hline Strombus pugilis & S. pugilis & Planktotrophic & Caenogastropoda & 3 & 7 \\
\hline Laevistrombus canarium & Strombus canarium & Planktotrophic & Caenogastropoda & 2 & 21 \\
\hline Echinolittorina hawaiiensis & Littorina picta & Planktotrophic & Caenogastropoda & 1 & 28 \\
\hline Lobatus costatus & Strombus costatus & Planktotrophic & Caenogastropoda & 1 & 19 \\
\hline Ceraesignum maximum & Dendropoma maximum & Planktotrophic & Caenogastropoda & 1 & 5 \\
\hline Crepipatella lingulata & Crepidula lingulata & Planktotrophic & Caenogastropoda & 1 & 3 \\
\hline Crepipatella peruviana & Crepipatella fecunda & Planktotrophic & Caenogastropoda & 1 & 3 \\
\hline Cryptonatica janthostoma & C. janthostoma & Planktotrophic & Caenogastropoda & 1 & 1 \\
\hline Littorina littorea & L. littorea & Planktotrophic & Caenogastropoda & 1 & 1 \\
\hline Peringia ulvae & Hydrobia ulvae & Planktotrophic & Caenogastropoda & 1 & 1 \\
\hline Bittiolum alternatum & Bittium alternatum & Planktotrophic & Caenogastropoda & 1 & 1 \\
\hline Concholepas concholepas & C. concholepas & Planktotrophic & Caenogastropoda Neogastropoda & 4 & 13 \\
\hline Tritia obsoleta & Ilyanassa obsoleta & Planktotrophic & Caenogastropoda Neogastropoda & 4 & 12 \\
\hline Babylonia areolata & B. areolata & Planktotrophic & Caenogastropoda Neogastropoda & 2 & 4 \\
\hline Dicathais orbita & D. orbita & Planktotrophic & Caenogastropoda Neogastropoda & 1 & 21 \\
\hline Rapana venosa & R. venosa & Planktotrophic & Caenogastropoda Neogastropoda & 1 & 16 \\
\hline Babylonia formosae habei & B. formosae habei & Planktotrophic & Caenogastropoda Neogastropoda & 1 & 10 \\
\hline Conus flavidus & C. flavidus & Planktotrophic & Caenogastropoda Neogastropoda & 1 & 3 \\
\hline Conus marmoreus & C. marmoreus & Planktotrophic & Caenogastropoda Neogastropoda & 1 & 3 \\
\hline Conus striatus & C. striatus & Planktotrophic & Caenogastropoda Neogastropoda & 1 & 3 \\
\hline Conus lividus & C. lividus & Planktotrophic & Caenogastropoda Neogastropoda & 1 & 2 \\
\hline Conus pennaceus & C. pennaceus & Planktotrophic & Caenogastropoda Neogastropoda & 1 & 2 \\
\hline Conus quercimus & C. quercinus & Planktotrophic & Caenogastropoda Neogastropoda & 1 & 1 \\
\hline Kelletia kelletii & K. kelletii & Planktotrophic & Caenogastropoda Neogastropoda & 1 & 1 \\
\hline Onchidium reevesii & Onchidium struma & Planktotrophic & Heterobranchia & 2 & 4 \\
\hline Aplysia californica & A. californica & Planktotrophic & Heterobranchia & 1 & 27 \\
\hline Spurilla neapolitana & S. neapolitana & Planktotrophic & Heterobranchia & 1 & 3 \\
\hline Elysia viridis & E. viridis & Planktotrophic & Heterobranchia & 1 & 2 \\
\hline Philine aperta & P. aperta & Planktotrophic & Heterobranchia & 1 & 2 \\
\hline Amphibola crenata & A. crenata & Planktotrophic & Heterobranchia & 1 & 1 \\
\hline Hydatina physis & H. physis & Planktotrophic & Heterobranchia & 1 & 1 \\
\hline Palio dubia & P. dubia & Planktotrophic & Heterobranchia & 1 & 1 \\
\hline Babylonia formosae & B. formosae & Lecithotrophic & Caenogastropoda Neogastropoda & 1 & 4 \\
\hline Adalaria proxima & A.proxima & Lecithotrophic & Heterobranchia & 1 & 2 \\
\hline Lottia digitalis & L. digitalis & Lecithotrophic & Patellogastropoda & 1 & 2 \\
\hline Haliotis rufescens & H. rufescens & Lecithotrophic & Vetigastropoda & 12 & 60 \\
\hline Haliotis diversicolor & $H$. diversicolor & Lecithotrophic & Vetigastropoda & 5 & 30 \\
\hline Haliotis iris & H. iris & Lecithotrophic & Vetigastropoda & 5 & 15 \\
\hline Haliotis discus hannai & H. discus hannai & Lecithotrophic & Vetigastropoda & 3 & 4 \\
\hline Haliotis asinina & H. asinina & Lecithotrophic & Vetigastropoda & 2 & 12 \\
\hline Haliotis rubra & H. rubra & Lecithotrophic & Vetigastropoda & 2 & 12 \\
\hline Haliotis laevigata & H. laevigata & Lecithotrophic & Vetigastropoda & 2 & 9 \\
\hline Haliotis discus & H. discus & Lecithotrophic & Vetigastropoda & 2 & 6 \\
\hline Haliotis australis & H. australis & Lecithotrophic & Vetigastropoda & 1 & 26 \\
\hline Haliotis virginea & H. virginea & Lecithotrophic & Vetigastropoda & 1 & 15 \\
\hline Haliotis kamtschatkana & H. kamtschatkana & Lecithotrophic & Vetigastropoda & 1 & 1 \\
\hline Haliotis mariae & H. mariae & Lecithotrophic & Vetigastropoda & 1 & 1 \\
\hline Tectus pyramis & $T$. pyramis & Lecithotrophic & Vetigastropoda & 1 & 1 \\
\hline Alderia modesta & A. modesta & Poecilogony & Heterobranchia & 3 & 8 \\
\hline Tenellia adspersa & T. adspersa & Poecilogony & Heterobranchia & 1 & 4 \\
\hline Alderia willowi & A. willowi & Poecilogony & Heterobranchia & 1 & 2 \\
\hline Dendronotus frondosus & D. frondosus & Poecilogony & Heterobranchia & 1 & 2 \\
\hline Phestilla sibogae & P. sibogae & Poecilogony & Heterobranchia & 1 & 1 \\
\hline
\end{tabular}

Species are sorted within each major clade by the number of publications and then the number of experimental treatments for that species. 

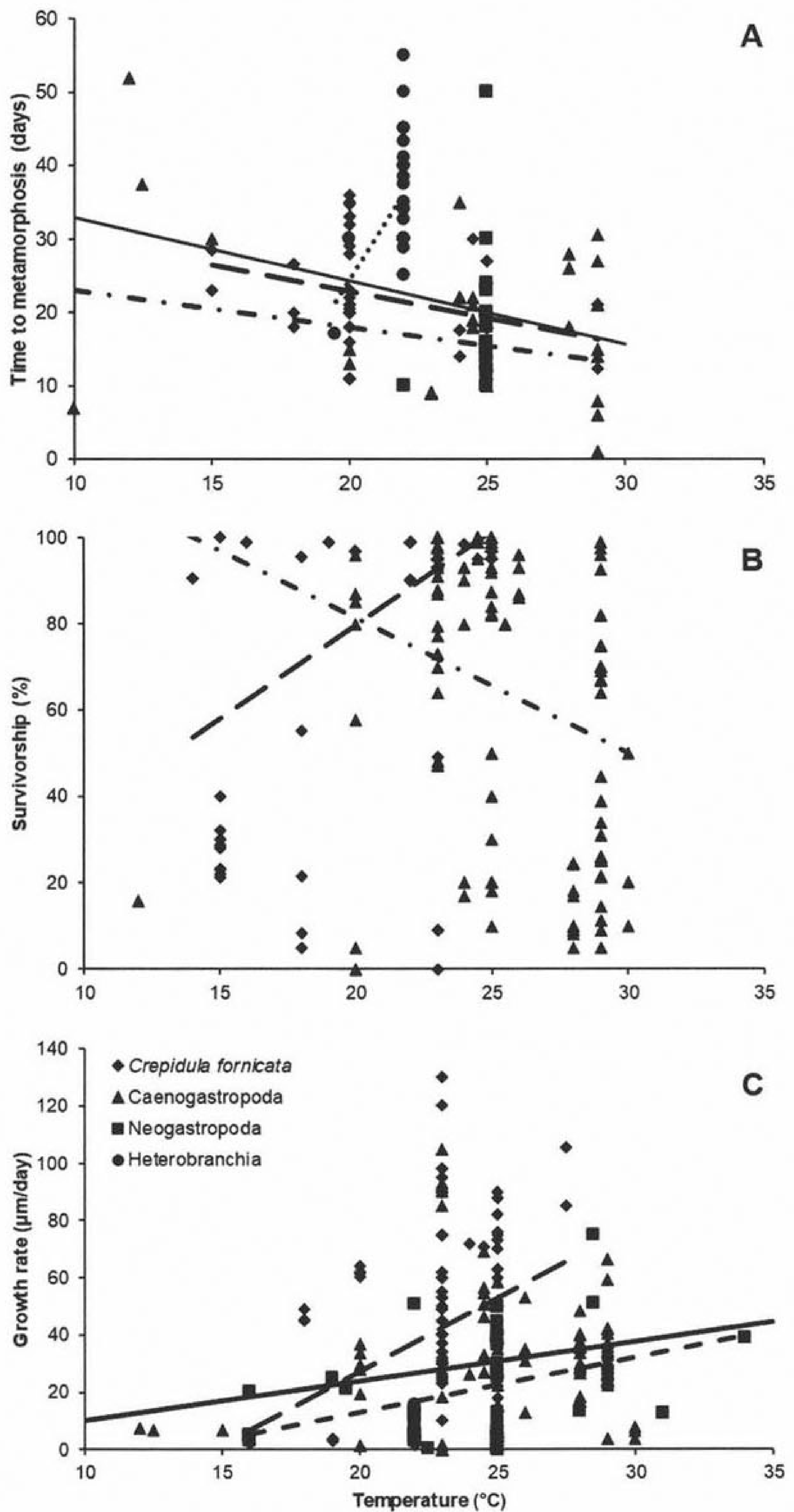

Figure 2. Effect of temperature on life history metrics for planktotrophic larvae. Regression lines [ordinary least squares (OLS)] are displayed only for groups with significant $(P \leq \mathbf{0 . 0 5})$ correlations ( - all data, -- Crepidula fornicata, -- Neogastropoda, $-\cdot-$ Caenogastropoda other than C. fornicata or Neogastropoda, and $\cdots$ Heterobranchia). (A) Temperature and time to metamorphosis. Significant correlations for all planktotrophs $\left(Y=-0.8642+41.614, R^{2}=0.0711\right), C$. fornicata $\left(Y=-0.6556 x+34.036, R^{2}=0.0942\right)$, and Heterobranchia $\left(Y=5.9578 x-94.724, R^{2}=0.2011\right)$. (B) Temperature and \% survivorship. Significant correlations for $C$. fornicata $\left(Y=4.3415 x-7.2052, R^{2}=0.233\right)$ and Caenogastropoda other than C. fornicata and Neogastropoda $\left(Y=-3.1308+143.86, R^{2}=0.0767\right)$. (C) Temperature and growth rate. Significant correlations for all planktotrophs $\left(Y=1.3745 x-3.5672, R^{2}=0.032\right), C$. fornicata $\left(Y=5.124 x-75.149, R^{2}=0.123\right)$, and Neogastropoda $(Y=1.9137 x-25.282$, $\left.R^{2}=0.1483\right)$. 


\section{Survivorship}

There were data for survivorship and temperature for 314 $(48.7 \%)$ experimental treatments with planktotrophic larvae. There was no effect of temperature on survivorship for planktotrophic larvae overall $(n=314, P=0.172)$, or for the Neogastropoda $(n=45, P=0.600)$ or Heterobranchia $(n=28, P=0.165)$. There was a positive correlation between temperature and survivorship for Crepidula fornicata $(n=116$, $P<0.0001, r=0.483$ ), the single most studied species with planktotrophic larvae. There was, however, a negative correlation between temperature and survivorship for the remaining caenogastropods other than $C$. fornicata that were not neogastropods ( $n=127, P=0.002, r=-0.277$; Fig. 2).

\section{Growth}

There were data on growth and temperature for $273(42.3 \%)$ experimental treatments with planktotrophic larvae. Overall, there was a significant positive effect of temperature on feeding larval growth ( $n=273, P<0.003, r=0.179$; Fig. 2$)$. There was no correlation between temperature and growth for the caenogastropods that were not Crepidula fornicata or neogastropods ( $n=109, P=0.216$ ), but there was a positive correlation for C. fornicata $(n=87, P=0.0008, r=0.351$; Fig. 2$)$ and for the neogastropods ( $n=50, P=0.0057, r=0.385$; Fig. 2). All experiments with heterobranchs were conducted at the same temperature.

\section{Larval Density}

\section{Time to Metamorphosis}

Of the 645 experimental treatments with planktotrophic larvae, only $140(21.7 \%)$ reported both larval density and time to metamorphosis. For planktotrophic larvae, overall, there was a significant positive correlation between larval density and time to metamorphosis ( $n=140, P<0.0001, r=0.354$; Fig. 3 ). At higher larval densities, time to metamorphosis was longer. This pattern was driven primarily by species of Caenogastropoda other than Crepidula fornicata that were not in the Neogastropoda ( $n=51, P=0.0022, r=0.420$; Fig. 3 ) and the Heterobranchia $(n=24, P=0.0003, r=0.707$; Fig. 3 ). For Neogastropoda $(n=18$, $P=0.1027)$ and $C$. fornicata $(n=47, P=0.825)$, there was no correlation between larval density and time to metamorphosis.

\section{Survivorship}

There were data for survivorship and larval density for 311 $(48.2 \%)$ experimental treatments with planktotrophic larvae. There was no overall effect of larval density on survivorship ( $n=311, P=0.065)$, or for just the Caenogastropoda $(n=283$, $P=0.982)$ or for Neogastropoda $(n=45, P=0.354)$. There was a negative correlation between larval density and survivorship for Crepidula fornicata ( $n=115, P<0.0001, r=-0.346$; Fig. 3 ) and a negative correlation between survivorship and larval density for Heterobranchia $(n=28, P=0.017, r=-0.448$; Fig. 3). There was a positive correlation between larval density for species of caenogastropod other than $C$. fornicata that were not neogastropods ( $n=123, P=0.008, r=0.241$; Fig. 3 ).

\section{Growth}

There were data on both larval density and growth for 283 $(43.9 \%)$ experimental treatments with planktotrophic larvae.
Overall, there was no effect of larval density on growth ( $n=283, P=0.075)$, or for all caenogastropods $(n=256, P=$ 0.383 ; Fig. 3 ); however, there was a significant positive correlation for Neogastropoda ( $n=49, P=0.0023, r=0.427$; Fig. 3$)$ and a significant negative correlation between larval density and growth for Crepidula fornicata $(n=99, P=0.028, r=-0.221$; Fig. 3). There was also no correlation between larval density and growth for the Heterobranchia $(n=27, P=0.661)$.

\section{Food Density}

\section{Time to Metamorphosis}

Of the 645 experimental treatments with planktotrophic larvae, only $127(19.7 \%)$ reported both food density and time to metamorphosis. For planktotrophic larvae, overall, there was a significant positive correlation between food density and time to metamorphosis ( $n=127, P<0.001, r=0.321$; Fig. 4 ). This pattern, however, was driven by differences among taxa. There was no significant correlation for all caenogastropods together ( $n=103, P=0.576$ ), or caenogastropods other than Crepidula fornicata or the neogastropods $(n=46, P=0.933)$. For neogastropods $(n=10, P=0.069)$ and heterobranchs ( $n=24, P=0.238$ ), there was also no significant correlation between food density and time to metamorphosis. For C. fornicata, all experiments that reported both food density and time to metamorphosis $(n=47)$ were conducted with the same food density $\left(1.8 \times 10^{5}\right.$ cells $\left./ \mathrm{mL}\right)$. At this food density, reported time to metamorphosis ranged from 11 to 36 days.

\section{Survivorship}

There were data for survivorship and planktonic food density for $290(44.9 \%)$ experimental treatments with planktotrophic larvae. There was no overall effect of food density on survivorship ( $n=290, P=0.381)$. There was no correlation between food density and survivorship for all of the Caenogastropoda $(n=262, P=0.330)$, for just the Neogastropoda ( $n=28, P=0.350)$, or for Crepidula fornicata $(n=115$, $P=0.689$ ). Similarly, there was no correlation for the Heterobranchia $(n=28, P=0.459)$.

\section{Growth}

There were data on food density and growth for 248 $(38.6 \%)$ experimental treatments with planktotrophic larvae. Overall, there was no significant effect of food density on growth $(n=248, P=0.932)$. This pattern was consistent for all caenogastropods $(n=221, P=0.752)$ and caenogastropods other than Crepidula fornicata that were not neogastropods $(n=106, P=0.891)$. For $C$. fornicata $(n=87, P<0.001$, $r=0.522$; Fig. 4) and neogastropods $(n=28, P=0.001$, $r=0.611$; Fig. 4), however, there was a significant positive correlation between food density and larval growth. There was no correlation for the heterobranchs $(n=27, P=0.870)$.

\section{Per Capita Food Availability}

\section{Time to Metamorphosis}

Of the 645 experimental treatments with planktotrophic larvae, only $111(17.2 \%)$ reported per capita food availability (food concentration and larval concentration) and time to metamorphosis. For planktotrophic larvae, overall, there was 

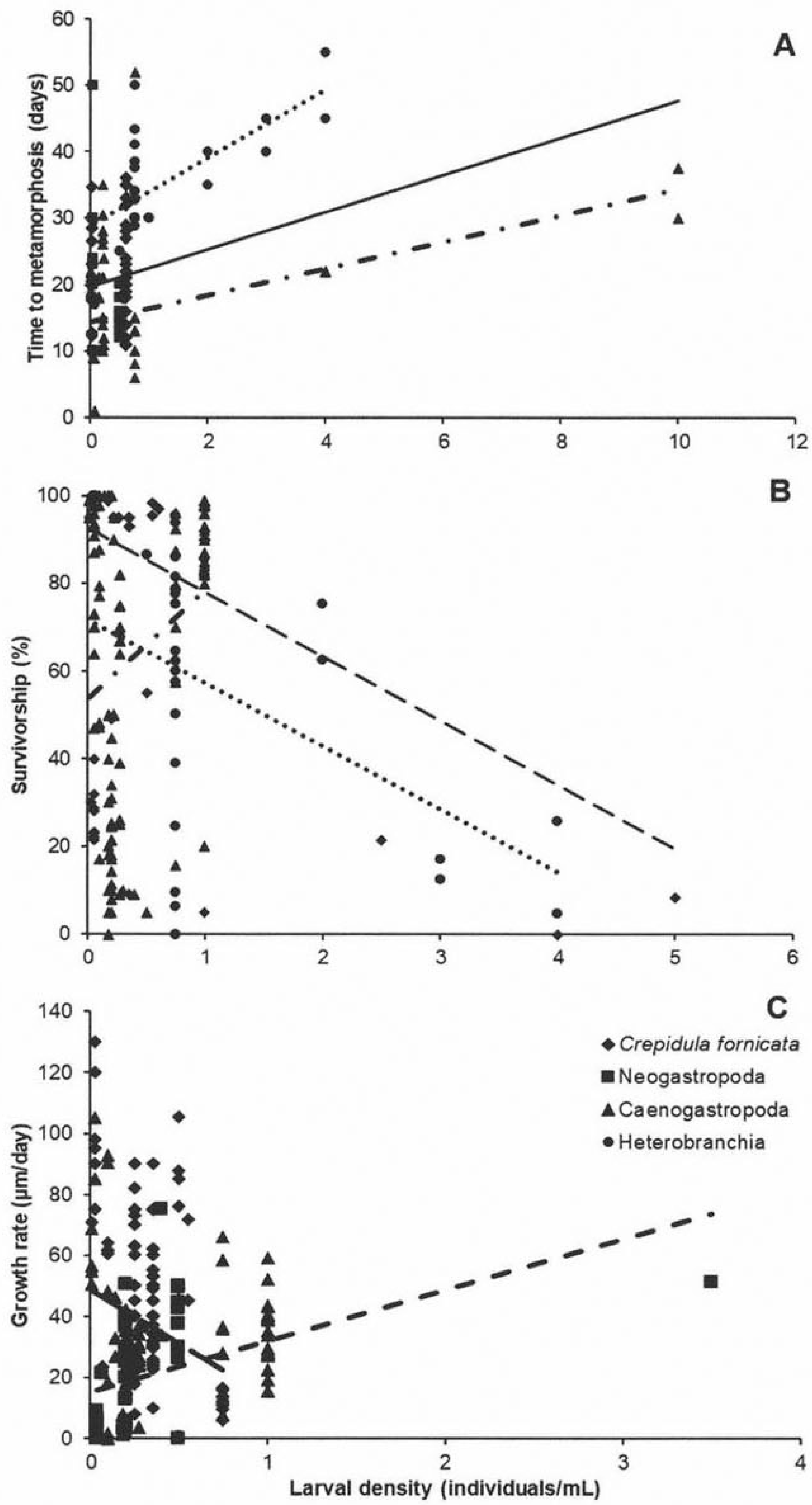

Figure 3. Effects of larval density on life history metrics for planktotrophic larvae. Ordinary least squares regression lines are displayed only for groups with significant $(P \leq 0.05)$ correlations ( - all data, - Crepidula fornicata, -- Neogastropoda, $-\bullet-$ Caenogastropoda other than $C$. fornicata or Neogastropoda, and $\cdots$ Heterobranchia). (A) Larval density and time to metamorphosis. Significant correlations for all planktotrophs $(Y=2.7891 x+$ $\left.19.759, R^{2}=0.1245\right)$, Caenogastropoda that are neither $C$. fornicata nor neogastropods $\left(Y=1.9633 x+14.744, R^{2}=0.1758\right)$, and Heterobranchia $\left(Y=5.1343 x+28.85, R^{2}=0.4495\right)$. (B) Larval density and \% survivorship. Significant correlations for $C$. fornicata $\left(Y=-14.655 x+92.64, R^{2}=0.1198\right)$, Caenogastropoda other than $C$. fornicata or Neogastropoda $\left(Y=24.531 x+53.818, R^{2}=0.0577\right)$, and Heterobranchia $(Y=-14.407+71.654$, $\left.R^{2}=0.2006\right)$. (C) Larval density and growth rate. Significant correlations for $C$. fornicata $\left(Y=-35.021 x+48.806, R^{2}=0.0486\right)$ and Neogastropoda $\left(Y=16.721 x+15.263, R^{2}=0.1815\right)$. 

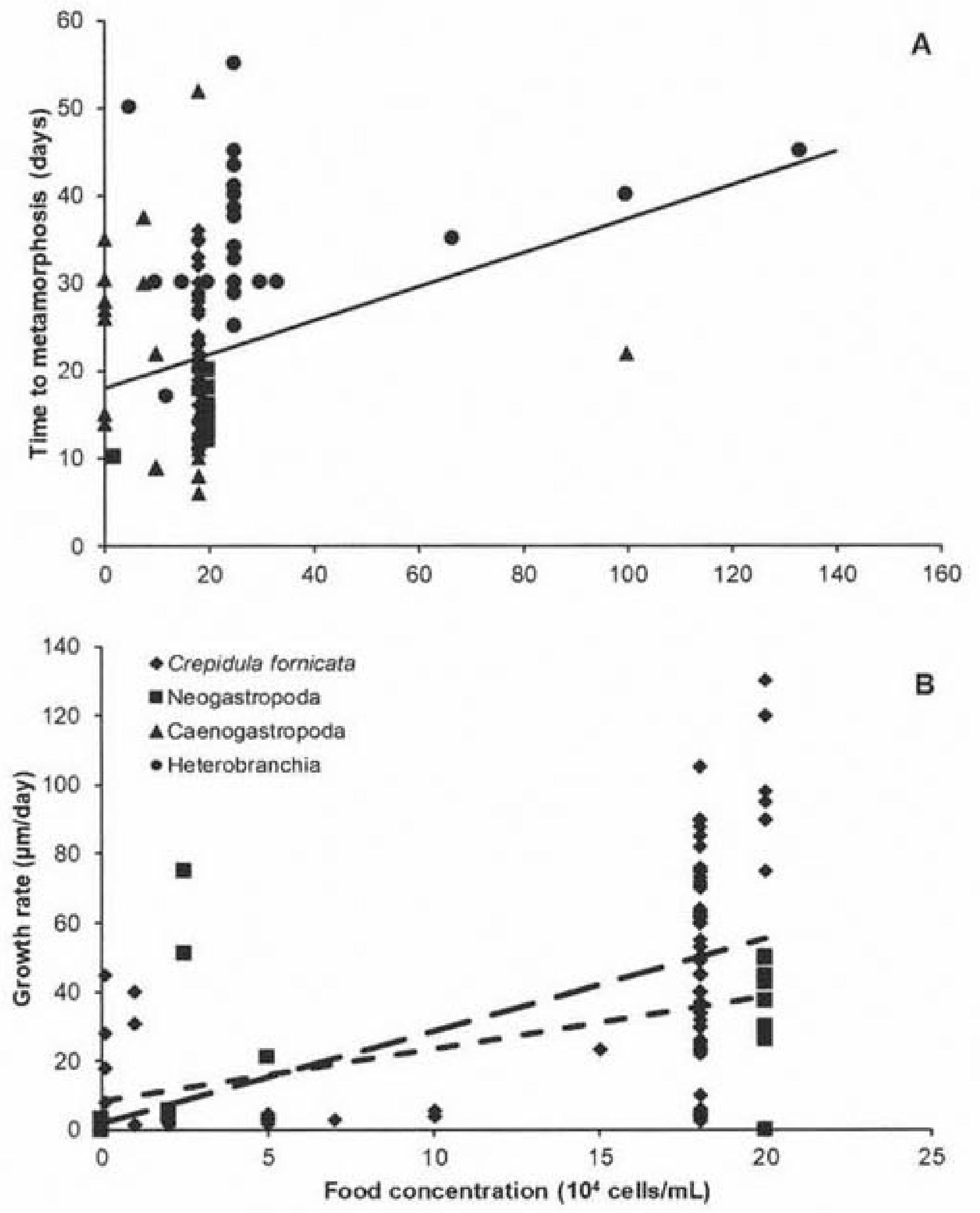

Figure 4. Effects of food concentration on life history metrics for planktotrophic larvae. Ordinary least squares regression lines are displayed only for groups with significant $(P \leq 0.05)$ correlations ( - all data, -- Crepidula fornicata, and - - Neogastropoda). (A) Food concentration and time to metamorphosis. Significant correlation for all planktotrophs ( $Y=2 \times$ $\left.10^{-5} x+17.917, R^{2}=0.1034\right)$. (B) Food concentration and growth rate. Significant correlations for $C$. fornicata $\left(Y=0.0003 x+1.8521, R^{2}=0.2728\right)$ and Neogastropoda $\left(Y=0.0002 x+8.3205, R^{2}=0.3737\right)$.

no significant correlation between per capita food availability and time to metamorphosis $(n=111, P=0.538)$. Within taxa, there was also no correlation except for the heterobranchs, which showed a negative correlation $(n=24, P=0.002$, $r=-0.609$; Fig. 5). Removal of the outlier data point did not change the significance of this correlation $(n=23, P=0.004$, $r=-0.573$ ). There was no correlation for all caenogastropods together $(n=87, P=0.566)$, for caenogastropods other than Crepidula fornicata that were not neogastropods $(n=31$, $P=0.856)$, or for $C$. fornicata $(n=47, P=0.410)$. All experiments with Neogastropoda $(n=9)$ were conducted with the same per capita food availability.

\section{Survivorship}

There were data for survivorship and per capita food availability for $259(40.2 \%)$ experimental treatments with planktotrophic larvae. There was no overall effect of per capita food density on survivorship $(n=259, P=0.653)$. But, there was a significant positive correlation for the Heterobranchia $(n=28, P=0.028, r=0.415$; Fig. 5$)$. There was no correlation between per capita food density and survivorship for the Caenogastropoda overall $(n=231$, $P=0.798)$ or the Caenogastropoda other than Crepidula fornicata that were not neogastropods $(n=102, P=0.205)$.
There was a significant positive correlation between per capita food availability and survivorship for the neogastropods $(n=18$, $P<0.0001, r=0.887)$. Survivorship increased with increased per capita food availability. For $C$. fornicata, there was a significant negative correlation between per capita food availability and survivorship $(n=111, P=0.033, r=-0.202)$; higher per capita food availability was associated with lower survivorship.

\section{Growth}

There were data on per capita food availability and growth for $242(37.3 \%)$ experimental treatments with planktotrophic larvae. Overall, there was a significant positive effect of per capita food density on growth ( $n=242, P=0.001, r=0.202$; Fig. 5 ). This pattern was consistent for all of the caenogastropods together $(n=215, P=0.006, r=0.187$; Fig. 5), for caenogastropods other than Crepidula fornicata that were not neogastropods $(n=106$, $P=0.026, r=0.217$; Fig. 5), for just $C$. fornicata $(n=82$, $P=0.005, r=0.374 ;$ Fig. 5 ), and for just the neogastropods ( $n=$ $27, P=0.002, r=0.560$; Fig. 5). There was no correlation, however, for the heterobranchs $(n=27, P=0.128)$.

\section{Lecithotrophic Larvae}

For species with lecithotrophic larvae, there were 46 articles, 81 experiments, and a total of 216 experimental treatments for 27 currently recognized species or subspecies of gastropods from only five genera (Table 1). This included one species of Patellogastropoda, 13 species of Vetigastropoda, 12 of which are in the genus Haliotis, one species of Caenogastropoda that is also in the Neogastropoda, and one species in the Heterobranchia. The vast majority of the gastropods studied were herbivores, and only one was a predator and one was a scavenger.

Of the species with lecithotrophic larvae that were found in the literature search, only two live in the intertidal zone; the rest were species found in the subtidal zone. As for the gastropod species with planktotrophic larvae, studied species were from a wide range of geographic areas including China, Sea of Japan, Indonesia, Russia, North American Pacific coast, North American Atlantic, South American Pacific Coast, Atlantic coast in Europe, North Africa, Mediterranean, Arabian Sea, the Indian Ocean, the Indo-Pacific, New Zealand, and Australia. Nine of the recognized species and subspecies with lecithotrophic larvae are grown in aquaculture.

Lecithotrophic larvae were the focus of $37 \%$ (46) of all of the publications in the review. For lecithotrophic larvae, there were 81 different experiments and 216 total different treatment levels. Temperature was reported in $80 \%$ treatments that focused on lecithotrophic larvae and $44 \%$ reported time to metamorphosis.

\section{Temperature}

\section{Time to Metamorphosis}

Of the 216 experimental treatments with lecithotrophic larvae, only $76(35 \%)$ reported both temperature and time to metamorphosis. For nonfeeding larvae, overall, there was no significant correlation between temperature and time to metamorphosis $(n=76, P=0.654)$. There was a significant positive correlation, however, for the Heterobranchia $(n=9, P=0.012$, $r=0.786$; Fig. 6 ). This correlation was primarily driven by a single outlying point; removal of that one data point resulted in no 

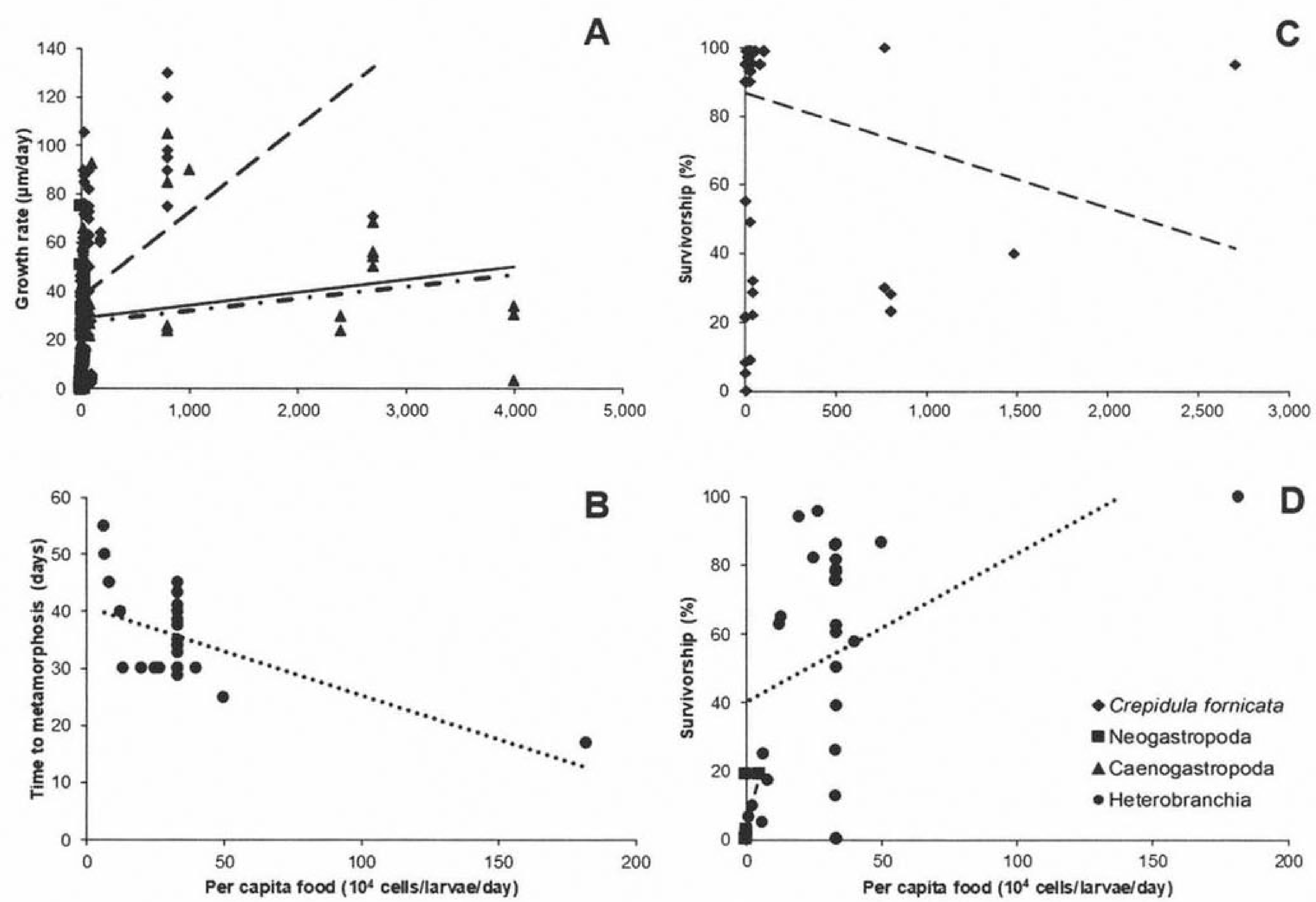

Figure 5. Effect of food per capita on life history metrics for planktotrophic larvae. Ordinary least squares regression lines are displayed only for groups with significant $(P \leq 0.05)$ correlations ( - all data, -- Crepidula fornicata, -- Neogastropoda, $-\bullet-$ Caenogastropoda other than $C$. fornicata or Neogastropoda, and ... Heterobranchia). (A) Food per capita and growth rate. Significant correlations for all planktotrophs $\left(Y=9 \times 10^{7} x+28.894, R^{2}\right.$ $=0.0414), C$. fornicata $\left(Y=4 \times 10^{-6} x+37.629, R^{2}=0.1399\right)$, Neogastropods $\left(Y=7 \times 10^{-5} x+9.169, R^{2}=0.3136\right)$, and Caenogastropoda other than C. fornicata or Neogastropoda $\left(Y=5 \times 10^{-7}+26.972, R^{2}=0.0467\right)$. (B) Food per capita and time to metamorphosis. Significant correlation for Heterobranchia $\left(Y=-2 \times 10^{-5} x+40.786, R^{2}=0.371\right)$. (C) Food per capita and $\%$ survivorship for $C$. fornicata alone $\left(Y=-2 \times 10^{-6} x+86.808, R^{2}=\right.$ 0.041). (D) Food per capita and \% survivorship for all taxonomic groups except $C$. fornicata. Significant correlations for Neogastropoda $(Y=0.0003 x+$ $\left.2.7539, R^{2}=0.7866\right)$ and Heterobranchia $\left(Y=4 \times 10^{-5} x+40.308, R^{2}=0.1719\right)$.

correlation $(n=8, P=0.259)$. These data were from only three publications (Miller \& Hadfield 1986, Chester 1996, Sisson 2002), and eight of the experimental treatments were for two closely related species, Tenellia adspersa and Phestilla sibogae. There was a significant negative correlation for the Vetigastropoda $(n=61$, $P=0.0106, r=-0.325$ ); vetigastropods developed slower at higher temperatures. The abalone Haliotis rufescens was the most studied species with nonfeeding larvae. There were only five experimental treatments (from four publications) where both temperature and time to metamorphosis were reported. For the available data, there was no significant relationship $(n=5, P=0.460)$.

\section{Survivorship}

There were data for survivorship and temperature for $72(33.3 \%)$ experimental treatments with nonfeeding larvae. For neogastropods, all six experimental treatments were conducted at the same temperature and had the same survivorship. But, there was a significant negative correlation between temperature and survivorship for lecithotrophic larvae overall $(n=72$, $P=0.002, r=-0.356$; Fig. 6). Similarly, there was a significant negative correlation between temperature and survivorship for heterobranchs ( $n=6, P=0.004, r=-0.950$; Fig. 6), as well as for the vetigastropods $(n=60, P=0.005, r=-0.354$; Fig. 6). For Haliotis rufescens ( $n=26, P<0.0001, r=-0.830)$, the single most studied species of lecithotroph, again there was a negative correlation between temperature and survivorship. The data for this species seem to indicate a temperature threshold, below which survivorship drops (Fig. 6). There were too few data to determine if other species show a similar threshold pattern.

\section{Growth}

There were data on growth and temperature for only nine experimental treatments for nonfeeding larvae, and all studies were on vetigastropods. There was no significant effect of temperature on larval growth for this group $(n=9, P=0.178)$.

\section{Larval Density}

Time to Metamorphosis

Of the 216 experimental treatments with nonfeeding larvae, only $66(30.5 \%)$ reported both larval density and time to 

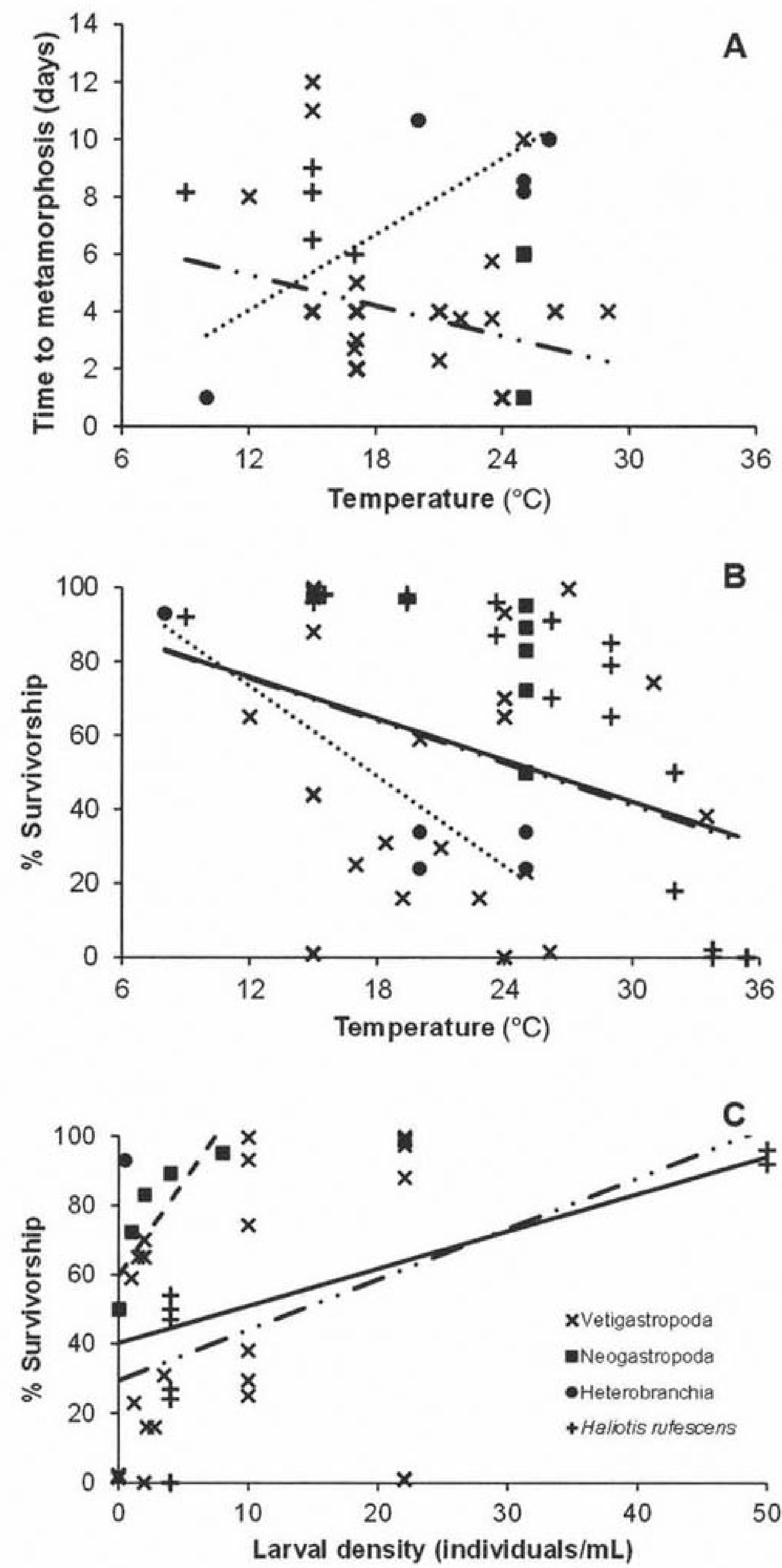

Figure 6. Factors affecting life history metrics of lecithotrophic larvae. Ordinary least squares regression lines are displayed only for groups with significant $(P \leq$ 0.05 ) correlations ( - all data, $-\cdots$-Vetigastropoda, -- Neogastropoda, and m.Heterobranchia). (A) Temperature and time to metamorphosis. Significant correlations for the Vetigastropoda $\left(Y=-0.1783 x+7.4177, R^{2}=0.1057\right)$ and the Heterobranchia $\left(Y=0.4407 x-1.2435, R^{2}=0.6174\right)$. (B) Temperature and \% survivorship. Significant correlations for all lecithotrophs $(Y=-1.8673 x+$ 98.179, $\left.R^{2}=0.1265\right)$, Vetigastropoda $\left(Y=-1.9007 x+98.234, R^{2}=0.1255\right)$, and Heterobranchia $\left(Y=-4.0524 x+121.93, R^{2}=0.9016\right)$. (C) Larval density and $\%$ survivorship. Significant correlations for all lecithotrophs $(Y=1.0753 x+$ 40.288, $\left.R^{2}=0.1105\right)$, Vetigastropoda $\left(Y=1.4588 x+29.511, R^{2}=0.2163\right)$, and Neogastropoda $\left(Y=5.4172 x+59.642, R^{2}=0.7246\right)$.

metamorphosis. For nonfeeding larvae, overall, there was no correlation between larval density and time to metamorphosis ( $n=66, P=0.3953$ ). Similarly, there were no correlations between larval density and time to metamorphosis for neogastropods $(n=6, P=0.1849)$ or for vetigastropods $(n=56, P=0.1003)$, including Haliotis rufescens $(n=4, P=0.7178)$. All heterobranchs that were studied $(n=4)$ had a larval density of 2 larvae $/ \mathrm{mL}$ and metamorphosed in 10 days.

Survivorship

There were data for survivorship and larval density for 51 $(23.6 \%)$ experimental treatments with lecithotrophic larvae. Overall, there was a positive correlation between larval density and survivorship ( $n=51, P=0.017, r=0.332$; Fig. 6). This relationship was driven by two outlying points; removal of those two data points resulted in no significant correlation ( $n=49, P=0.096$ ). There was a positive correlation between larval density and survivorship for neogastropods $(n=6$, $P=0.023, r=0.851$; Fig. 6$)$ and for vetigastropods $(n=43$, $P=0.0017, r=0.465$; Fig. 6$)$. For just Haliotis rufescens, there was a significant positive correlation $(n=11, P=0.002$, $r=0.818)$. There were data for only two experimental treatments with heterobranchs; therefore, it was not possible to test for a correlation for this clade.

\section{Growth}

There were data on larval density and growth for nine $(4.2 \%)$ experimental treatments with lecithotrophic larvae. All nine of these experimental treatments came from two studies (Pena 1985, Stott et al. 2004) and were for the same genus, Haliotis (Haliotis diversicolor aquatilis and Haliotis discus). Overall, there was a marginally significant positive effect of larval density on growth $(n=9, P=0.052, r=0.662)$, but this was driven by one outlier. When this point was removed, there was no significant relationship $(n=8, P=0.812)$.

\section{DISCUSSION}

Gastropod larvae have been studied in the laboratory for decades, with most publications on rearing larvae under experimental conditions through metamorphosis appearing since the mid-1960s (Fig. 1). Considerable information is available for certain species, particularly commercially important species, such as abalone (Haliotis spp.), as well as one species of slipper shell Crepidula fornicata. Although hundreds of studies have been published, surprisingly few report important metadata that allow general questions to be addressed. In addition, most studies have been carried out on relatively few species. This limits the ability to generalize across taxa.

All Patellogastropoda and Vetigastropoda have lecithotrophic larvae. Within the Caenogastropoda and Heterobranchia, there is a mixture of developmental types, but among those species studied, the vast majority are planktotrophs. To tell whether there are clade-specific patterns among taxa with planktotrophic development, more studies are needed on different species with planktotrophic development. Generally, species with lecithotrophic larvae are underrepresented in the literature, and more work is needed on species across clades with this developmental mode. Too few species with poecilogony were studied to determine if there were patterns associated with that mode of development.

Although many different factors could be confounded with, or contribute to, the patterns of time to metamorphosis, survivorship, and larval growth that were examined, some patterns within and across clades and modes of development 
did emerge. In all cases, there was considerable variance in the data, which is reflected in the relatively low correlations observed.

\section{Temperature}

For species with planktotrophic larvae, in general, increased temperature tended to decrease development time as measured by time to metamorphosis, except for the heterobranchs. There were conflicting patterns for the effects of temperature on larval survivorship. Across all planktotrophs, and for just the neogastropods and the heterobranchs, there was no correlation between temperature and survivorship. Warmer temperatures, however, were correlated with increased survivorship for Crepidula fornicata and decreased survivorship for the remaining caenogastropods. In general, increased temperature was correlated with increased growth except for caenogastropods other than $C$. fornicata or neogastropods (Table 2).

For gastropods with lecithotrophic larvae, increased temperature was correlated with shorter time to metamorphosis for vetigastropods, but the opposite was true for the heterobranchs. The sample size for heterobranchs, however, was quite small $(n=9)$. Across all taxa with lecithotrophic larvae, there was no pattern for effects of temperature on time to metamorphosis (Table 3).

For gastropods with lecithotrophic development, and all clades with sufficient sample sizes to test for correlations, increased temperature was correlated with decreased survivorship and had no effect on growth, but data on growth were very limited (Table 3).

Increased temperature is generally associated with increased metabolic rate and faster development (Clarke 2006, Pappalardo et al. 2014, Watson et al. 2014), which was seen in some, but not all, groups of both planktotrophic and lecithotrophic gastropod larvae. For gastropods with lecithotrophic larvae, including all clades that could be tested, increased temperature was associated with decreased survivorship, suggesting that there may be an energetic cost to more rapid development or to dealing with physiological stress of increased temperature. For most groups of gastropods with planktotrophic larvae, survivorship was not correlated with temperature. Exceptions were the caenogastropods other than Crepidula fornicata and neogastropods, which showed a similar trend as that seen for lecithotrophs. For $C$. fornicata, increased temperature was actually correlated with higher survivorship. The counter trend for $C$. fornicata is curious. Studies with this species fell within a narrower temperature range than those for other taxa. Clearly, more data are needed to test the effects of temperature on survivorship of $C$. fornicata over a wider range of temperature and for more taxa. In addition, data on the metabolic and physiological costs of temperature-dependent development rates, temperature stress, and the energetics of metabolic demand are needed.

\section{Larval Density}

Larval density can affect food competition for feeding larvae, as well as interference among larvae, reducing individual feeding time or efficiency. Overall, there were few, and sometimes conflicting, patterns for the association between larval density for gastropod species with planktotrophic development and the response metrics examined in this review. When all data for planktotrophic larvae were considered together, increased density was associated with an increase in the time to metamorphosis. This trend was, however, only apparent when all species were considered together. No significant pattern was found for species of caenogastropods other than Crepidula fornicata that were not neogastropods or for the heterobranchs. There was no relationship between larval density and development time for the neogastropods or for C. fornicata (Table 2). Although time to metamorphosis was not correlated with larval density for $C$. fornicata, increased larval density was correlated

TABLE 2.

Summary of correlations among factors examined for planktotrophic larvae.

\begin{tabular}{|c|c|c|c|c|c|c|}
\hline & \multicolumn{4}{|c|}{ Caenogastropoda } & \multirow[b]{2}{*}{ Heterobranchia } & \multirow[b]{2}{*}{$\begin{array}{c}\text { All } \\
\text { planktotrophs }\end{array}$} \\
\hline & All & $\begin{array}{c}\text { Non-Neogastropoda, } \\
\text { non-Crepidula fornicata }\end{array}$ & $\begin{array}{l}\text { Just } \\
\text { C. fornicata }\end{array}$ & $\begin{array}{c}\text { Just } \\
\text { Neogastropoda }\end{array}$ & & \\
\hline \multicolumn{7}{|l|}{ Temperature } \\
\hline Time to metamorphosis & $\downarrow n=113,18.4 \%$ & $\sim n=48,19.8 \%$ & $\downarrow n=47,16.7 \%$ & $\sim n=18,20.2 \%$ & $\uparrow n=25,78.1 \%$ & $\downarrow n=138,21.4 \%$ \\
\hline Survivorship & $\sim n=286,46.7 \%$ & $\downarrow n=130,53.5 \%$ & $\uparrow n=116,41.3 \%$ & $\sim n=45,50.6 \%$ & $\sim n=28,87.5 \%$ & $\sim n=314,48.7 \%$ \\
\hline Growth & $\uparrow n=246,40.1 \%$ & $\sim n=109,44.9 \%$ & $\uparrow n=87,31.0 \%$ & $\uparrow n=50,56.2 \%$ & - & $\uparrow n=273,42.3 \%$ \\
\hline \multicolumn{7}{|l|}{ Larval density } \\
\hline Time to metamorphosis & $\uparrow n=116,18.9 \%$ & $\uparrow n=51,21.0 \%$ & $\sim n=47,16.7 \%$ & $\sim n=18,20.2 \%$ & $\uparrow n=24,75.0 \%$ & $\uparrow n=140,21.7 \%$ \\
\hline Survivorship & $\sim n=283,46.2 \%$ & $\uparrow n=123,50.6 \%$ & $\downarrow n=115,40.9 \%$ & $\sim n=45,50.6 \%$ & $\downarrow n=28,87.5 \%$ & $\sim n=311,48.2 \%$ \\
\hline Growth & $\sim n=256,41.8 \%$ & $\sim n=108,44.4 \%$ & $\downarrow n=99,35.2 \%$ & $\uparrow n=49,55.1 \%$ & $\sim n=27,84.4 \%$ & $\sim n=283,43.9 \%$ \\
\hline \multicolumn{7}{|l|}{ Food density } \\
\hline Time to metamorphosis & $\sim n=103,16.8 \%$ & $\sim n=46,18.9 \%$ & - & $\sim n=10,11.2 \%$ & $\sim n=24,75.0 \%$ & $\uparrow n=127,19.7 \%$ \\
\hline Survivorship & $\sim n=262,42.7 \%$ & $\sim n=119,49.0 \%$ & $\sim n=115,40.9 \%$ & $\sim n=28,31.5 \%$ & $\sim n=28,87.5 \%$ & $\sim n=290,45.0 \%$ \\
\hline Growth & $\sim n=221,36.1 \%$ & $\sim n=106,43.6 \%$ & $\uparrow n=87,31.0 \%$ & $\uparrow n=28,31.5 \%$ & $\sim n=27,84.4 \%$ & $\sim n=248,38.6 \%$ \\
\hline \multicolumn{7}{|l|}{ Per capita food availability } \\
\hline Time to metamorphosis & $\sim n=87,14.2 \%$ & $\sim n=31,12.8 \%$ & $\sim n=47,16.7 \%$ & - & $\downarrow n=24,75.0 \%$ & $\sim n=111,17.2 \%$ \\
\hline Survivorship & $\sim n=231,37.7 \%$ & $\sim n=102,42.0 \%$ & $\downarrow n=111,39.5 \%$ & $\uparrow n=18,20.2 \%$ & $\uparrow n=28,87.5 \%$ & $\sim n=259,40.2 \%$ \\
\hline Growth & $\uparrow n=215,35.1 \%$ & $\uparrow n=106,43.6 \%$ & $\uparrow n=82,29.2 \%$ & $\uparrow n=27,30.3 \%$ & $\sim n=27,84.4 \%$ & $\uparrow n=242,37.3 \%$ \\
\hline
\end{tabular}

$\uparrow$ indicates a significant positive correlation, $\downarrow$ indicates a significant negative correlation, and $\sim$ indicates no significant correlation. - indicates calculation of a correlation was not possible. $n=$ sample size and the percent of the total number of experimental treatments for each clade. 
TABLE 3.

Summary of correlations among factors examined for lecithotrophic larvae.

\begin{tabular}{|c|c|c|c|c|c|}
\hline & Neogastropoda & Heterobranchia & Vetigastropoda & Patellogastropoda & $\begin{array}{c}\text { All } \\
\text { Lecithotrophs }\end{array}$ \\
\hline \multicolumn{6}{|l|}{ Temperature } \\
\hline Time to metamorphosis & - & $\uparrow n=9,56.3 \%$ & $\downarrow n=61,31.8 \%$ & - & $\sim n=76,35 \%$ \\
\hline Survivorship & - & $\downarrow n=6,37.5 \%$ & $\downarrow n=60,31.3 \%$ & - & $\downarrow n=72,33.3 \%$ \\
\hline Growth & - & - & $\sim n=9,4.7 \%$ & - & $\sim n=9,4.2 \%$ \\
\hline \multicolumn{6}{|l|}{ Larval density } \\
\hline Time to metamorphosis & $\sim n=6,100 \%$ & - & $\sim n=56,29.2 \%$ & - & $\sim n=66,30.5 \%$ \\
\hline Survivorship & $\uparrow n=6,100 \%$ & - & $\uparrow n=43,22.4 \%$ & - & $\uparrow n=51,23.6 \%$ \\
\hline Growth & - & - & $\uparrow^{*} n=9,4.7 \%$ & - & $\uparrow^{*} n=9,4.2 \%$ \\
\hline
\end{tabular}

$\uparrow$ indicates a significant positive correlation, $\downarrow$ indicates a significant negative correlation, $\sim$ indicates no significant correlation, and $*$ indicates correlation was marginally significant. - indicates calculation of a correlation was not possible. $n=$ sample size and the percent of the total number of experimental treatments for each clade.

with reduced survivorship. Increased larval density was also correlated with reduced survivorship for the heterobranchs; however, there was no overall trend in the effect of larval density on survivorship among planktotrophic species, or for the caenogastropods overall or the neogastropods. Surprisingly, increased larval density was correlated with higher survivorship for species of caenogastropods other than $C$. fornicata and neogastropods (Table 2), as was seen for species with lecithotrophic larvae (Table 3).

Overall, for species with planktotrophic larvae, there was no significant relationship between larval density and larval growth. There was also no relationship for the clades Heterobranchia or Caenogastropoda overall. Increased larval density was correlated with slower growth for Crepidula fornicata, but it was correlated with faster growth for neogastropods (Table 2). The lack of consistent patterns among clades may mean that density per se is relatively less important, and what is more important is how density affects other factors such as food availability (see per capita food availability). More data across taxa are needed before strong conclusions can be drawn.

For lecithotrophic larvae, there was no significant relationship between larval density and development time overall or among clades with enough data to test for a correlation (Table 3). For the studies included in this review, however, increased larval density was correlated with increased survivorship overall, as well as for just neogastropods and for just vetigastropods. Similarly, there was a positive relationship between larval density and growth rate, but this pattern was for only nine experimental treatments with vetigastropods; no other taxa were examined (Table 3). Positive correlations between larval density and survivorship or growth are curious and need further experiments across more taxa to determine if these relationships are robust. In addition, possible mechanisms that could produce this pattern are needed.

\section{Food Density}

Overall, increased food density was positively correlated with increased time to metamorphosis for all species with planktotrophic development; however, this pattern was driven by differences among clades. There was no relationship between food density and development time for any clade (Table 2). All studies that reported food density and time to metamorphosis for Crepidula fornicata were conducted at the same food density. Interestingly, when provided with the same food density, larval metamorphosis ranged more than 3 -fold, from 11 to 36 days. Thus, it appears that for this species, overall food density alone is not a major factor controlling development time. There was no relationship between food density and survivorship for planktotrophic larvae overall, or for any clade tested (Table 2). Increased food density was correlated with increased growth for neogastropods and for C. fornicata, but there was no similar correlation for other taxa or overall (Table 2).

\section{Per Capita Food Availability}

Per capita food availability combines the effects of larval density and food concentration. Interestingly, there was no relationship between per capita food availability and time to metamorphosis for planktotrophic larvae overall, for the caenogastropods overall, or for any group within the caenogastropods examined. There was a negative correlation between per capita food availability and time to metamorphosis for the heterobranchs, indicating that higher per capita food resulted in faster development. This result suggests that food competition among larvae is important for development time as this group showed no correlation between food density and time to metamorphosis and a positive correlation between larval density and time to metamorphosis (Table 2). Per capita food availability was correlated with higher survivorship for neogastropods and heterobranchs but was surprisingly correlated with reduced survivorship for Crepidula fornicata. This difference could be affected by differences among studies in the method used to determine survivorship. Further experimentation and documentation of methods are needed to determine if this pattern is robust. Overall, there was no correlation between per capita food availability and survivorship for planktotrophs. On the other hand, overall and for all of the different taxa considered, except the heterobranchs, which showed no pattern, faster larval growth was correlated with increased per capita food availability (Table 2). Again, this suggests that food competition among larvae may be most important. More experiments are needed that test these patterns directly across species, as well as with $C$. fornicata, as are studies designed to determine mechanisms that may be responsible for these patterns.

\section{Recommendations for Future Work}

Drawing strong inference from a review such as the one presented here has many limitations. In general, the ability to 
draw robust conclusions will always depend on the completeness of the data used to draw inference. Although the Gastropoda is the largest class of the Mollusca with more than 62,000 species, surprisingly few species (57) have been studied with experiments that follow the larval stage through metamorphosis. For this review, most species were represented by only a single publication, and many more species with planktotrophic development than those with lecithotrophic development have been studied. The analyses presented could not take into account the lack of independence created when different numbers of species, or species within a genus, are represented by a different number of studies, or the potential lack of independence due to the same set of investigators producing multiple studies, or the same geographic locations where studies were conducted. The one species that has been studied most extensively is the slipper snail Crepidula fornicata, which represents more than $26 \%$ of all publications considered in this review. It is clear, however, that it is not possible to attribute the findings for this species to all gastropods with planktotrophic development or even all caenogastropods with planktotrophic development. For only two cases, the relationship between warmer temperatures and faster growth rates, and the correlation between higher per capita food availability and faster larval growth, was there a consistent response across taxa that were also generally consistent with the response of $C$. fornicata. For the species with lecithotrophic larvae included in this review, overall patterns were generally more consistent across clades. Although there are many species of caenogastropod with lecithotrophic development, only a single species, Babylonia formosae (G. B. Sowerby II, 1866), was included in this review, precluding us from testing patterns for this clade. Most of the lecithotrophic species with enough data to include in this review were vetigastropods, primarily in the genus Haliotis ( 37 of 48 studies). Again, it is hard to draw general conclusions when so few species have been studied and when most studies are of closely related species.

Another challenge in finding generalizations among taxa is that most studies do not report all of the metadata needed to make comparisons among studies. To compare studies in the future, it is important that certain metadata always be included. Based on this review, recommendations would include always reporting the temperature at which experiments were run and the density of larvae in each experiment. For feeding larvae, it is also important to report actual food concentration (e.g., not ad libitum) and feeding frequency. Per capita food availability had an important impact on growth performance and, in some cases, survivorship of feeding larvae. Most studies $(17 \%-40 \%$ among clades) did not provide the information needed to calculate per capita food availability. By examining the effects of per capita food availability, the combined effects of food density and larval density could be assessed. With more data for more species, it would be feasible to examine the effects of multiple, potentially interacting factors. For example, with the data set assessed for this study, it was not possible to test combined effects of factors such as temperature and food concentration, or temperature and larval density on development time. The interplay of multiple factors may be responsible for some of the counterintuitive patterns detected in this study.

Equally important to the metadata are the response variables that are reported, and information on how those response variables were quantified. This review attempted to examine time to metamorphosis, as a general indicator of developmental rate, survivorship, and larval growth. Although not all studies have the same goals, in many cases, some of these data were collected during the course of an experiment but not reported in publications. In addition, not every study uses the same metrics to determine these response variables. For example, for time to metamorphosis, some articles report the date of first individual to metamorphose, whereas others report when $50 \%, 90 \%$, or $100 \%$ metamorphose. Whatever the case, where information is available, it would be most valuable if it is all reported. For survivorship, it was found that different studies calculated survivorship differently. In some cases, missing individuals were counted as mortality, whereas in other cases, missing individuals were not counted as mortality. In the latter case, if only $80 \%$ of individuals were recovered and no dead larvae were found, it would be reported as $100 \%$ survivorship. Again, to get around this problem, simply reporting all data would be most useful, and providing details of how metrics such as survivorship are determined is essential. Reports of growth are typically more uniform across studies, where the change in size over a certain number of days is reported, and typically the age of the larvae is provided. Although reporting all of these performance metrics can be time consuming (particularly measuring growth or extending an experiment until most animals metamorphose), the ability to determine if there are general patterns among species with particular developmental modes, or among major taxa or species will increase with the availability of more data on different species.

Ultimately, the ability to examine all of the patterns discussed in this review in a phylogenetic context is needed. This will require good phylogenies at the species level within and across clades. When such phylogenies are available, comparative methods can be used to address questions about the evolution of developmental mode or life history traits, and the impacts of factors such as food abundance, temperature, and larval density.

\section{ACKNOWLEDGMENTS}

This work was funded in part by NSF grant IOS-0920032 (D. K. P.) and NSF DBI-1611997 (M. R.). This is contribution number 1252 of the Department of Ecology and Evolution, Stony Brook University.

\section{LITERATURE CITED}

Chester, C. M. 1996. The effect of adult nutrition on the reproduction and development of the estuarine nudibranch, Tenellia adspersa (Nordmann, 1845). J. Exp. Mar. Biol. Ecol. 198:113-130.

Clarke, A. 2006. Temperature and the metabolic theory of ecology. Funct. Ecol. 20:405-412.

Krug, P. J., D. Gordon \& M. R. Romero. 2012. Seasonal polyphenism in larval type: rearing environment influences the development mode expressed by adults in the sea slug Alderia willowi. Integr. Comp. Biol. 52:161-172.

Miller, S. E. \& M. G. Hadfield. 1986. Ontogeny of phototaxis and metamorphic competence in larvae of the nudibranch Phestilla sibogae Bergh (Gastropoda: Opisthobranchia). J. Exp. Mar. Biol. Ecol. 97:95-112.

Padilla, D. K., M. J. McCann, M. McCarty Glenn, A. P. Hooks \& S. E. Shumway. 2014. Effect of food on metamorphic 
competence in the model system Crepidula fornicata. Biol. Bull. 227:242-251.

Pappalardo, P., E. Rodrıguez-Serrano \& M. Fernandez. 2014. Correlated evolution between mode of larval development and habitat in muricid gastropods. PLoS One 9:e94104.

Pena, J. B. 1985. The culture of Haliotis discus Reeve (Gastropoda; Prosobranchia) from fertilization to one-year-old in laboratory conditions. Iberus 5:21-30.

Perron, F. E. 1981. Larval growth and metamorphosis of Conus (Gastropoda: Toxoglossa) in Hawaii. Pac. Sci. 35:25-38.

Pullin, A. S. \& G. B. Stewart. 2006. Guidelines for systematic review in conservation and environmental management. Conserv. Biol. 20:1647-1656.
Seelemann, U. 1967. Rearing experiments on the amphibian slug Alderia modesta. Helgoland. Wiss. Meer. 15:128-134.

Sisson, C. D. 2002. Dichotomous life history patterns for the nudibranch Dendronotus frondosus (Ascanius, 1774) in the Gulf of Maine. Veliger 45:290-298.

Stott, A. E., T. Takeuchi \& Y. Koike. 2004. An alternative culture system for the hatchery production of abalone without using livefood. Aquaculture 236:341-360.

Watson, S.-A., S. A. Morley, A. E. Bates, M. S. Clark, R. W. Day, M. Lamare, S. M. Martin, P. C. Southgate, K. S. Tan, P. A. Tyler \& L. S. Peck. 2014. Low global sensitivity of metabolic rate to temperature in calcified marine invertebrates. Oecologia 174:45-54.

\section{LITERATURE USED IN THIS REVIEW}

Affan, M. A., H. S. Khomayis, J. Lee, S. M. Al-Harbi, H. E. Touliabah \& N. I. Abdulwassi. 2015. Settlement and growth of larval and juvenile abalone on single and mixed strains of benthic diatoms. Thalassas 31:59-65.

Aranda, D. A., A. Lucas, T. Brule, E. Salguero \& F. Rendon. 1989. Effects of temperature, algal food, feeding rate and density on the larval growth of the milk conch (Strombus costatus) in Mexico. Aquaculture 76:361-371.

Balkhair, M. A., A. R. Al-Mushikhi \& M. V. Chesalin. 2013. Experimental grow-out of the Omani abalone Haliotis mariae Wood, 1828, in land-based tanks in Mirbat, Oman. J. Shellfish Res. 32:3744.

Barile, P. J., A. W. Stoner \& C. M. Young. 1994. Phototaxis and vertical migration of queen conch (Strombus gigas Linne) veliger larvae. J. Exp. Mar. Biol. Ecol. 183:147-162.

Blanchard, M., J. A. Pechenik, E. Giudicelli, J. Connan \& R. Robert. 2008. Competition for food in the larvae of two marine molluscs, Crepidula fornicata and Crassostera gigas. Aquat. Living Resour. 21:197-205.

Bohn, K., C. A. Richardson \& S. R. Jenkins. 2013. Larval microhabitat associations of the non-native gastropod Crepidula fornicata and effects on recruitment success in the intertidal zone. J. Exp. Mar. Biol. Ecol. 448:289-297.

Boxshall, A. J. 1999. The importance of flow and settlement cues to larvae of the abalone, Haliotis rufescens Swainson. J. Exp. Mar. Biol. Ecol. 254:143-167.

Brante, A., M. Fernández \& F. Viard. 2008. Effect of oxygen conditions on intracapsular development in two calyptraeid species with different modes of larval development. Mar. Ecol. Prog. Ser. 368:197-207.

Brito-Manzano, N. \& D. A. Aranda. 2002. Larval development model of Strombus gigas versus Strombus pugilis. Proc. Gulf Caribb. Fish. Inst. 53:266-275.

Brito-Manzano, N. \& D. A. Aranda. 2004. Development, growth and survival of the larvae of queen conch Strombus gigas under laboratory conditions. Aquaculture 242:479-487.

Brito-Manzano, N. \& D. A. Arada. 2013. Effect of photoperiod and feeding schedule on growth and survival of larvae of the fighting conch Strombus pugilis Linné, 1758 (Mollusca, Gastropoda). Aquaculture 408-409:47-50.

Cahill, A. E. \& S. A. Koury. 2016. Larval settlement and metamorphosis in a marine gastropod in response to multiple conspecific cues. PeerJ 4:e2295.

Cam, S. L., J. A. Pechenik, M. Cagnon \& F. Viard. 2009. Fast versus slow larval growth in an invasive marine mollusc: does paternity matter? J. Hered. 100:455-464.

Campos, E. O., A. Pinto, E. Bustos, S. R. Rodriguez \& N. C. Inestrosa. 1994. Metamorphosis of laboratory-reared larvae of Concholepas concholepas (Mollusca; Gastropoda). Aquaculture 126:299-303.
Capo, T. R., A. T. Bardales, P. R. Gillette, M. R. Lara, M. C. Schmale \& J. E. Serafy. 2009. Larval growth, development, and survival of laboratory-reared Aplysia califonica: effects of diet and veliger density. Comp. Biochem. Physiol. 149:215-223.

Chester, C. M. 1996. The effect of adult nutrition on the reproduction and development of the estuarine nudibranch, Tenellia adspersa (Nordmann, 1845). J. Exp. Mar. Biol. Ecol. 198:113-130.

Chiu, J. M. Y., T. Y. T. Ng, W. X. Wang, V. Thiyagarajan \& P. Y. Qian. 2007. Latent effects of larval food limitation on filtration rate, carbon assimilation and growth in juvenile gastropod Crepidula onyx. Mar. Ecol. Prog. Ser. 343:173-182.

Cob, Z. C., A. Arshad, J. S. Bujang \& M. A. Ghaffer. 2009. Seasonal variation in growth and survival of Strombus canarium (Linnaeus, 1758) larvae. Pak. J. Biol. Sci. 12:676-682.

Cob, Z. C., A. Arshad, J. S. Bujang, W. L. W. Muda \& M. A. Ghaffar. 2010. Metamorphosis induction of the dog conch Strombus canarium (Gastropoda: Strombidae) using cues associated with conch nursery habitat. J. Appl. Sci. 10:628-635.

Collin, R. 2000. Sex change, reproduction, and development of Crepidula adunca and Crepidula lingulata (Gastropoda: Calyptraeidae). Veliger 43:24-33.

Comtet, T. \& P. Riera. 2006. $\delta^{13} \mathrm{C}$ and $\delta^{15} \mathrm{~N}$ changes after dietary shift in veliger larvae of the slipper limpet Crepidula fornicata: an experimental evidence. Helgol. Mar. Res. 60:281-285.

Conroy, P. T., J. W. Hunt \& B. S. Anderson. 1996. Validation of a shortterm toxicity test endpoint by comparison with longer-term effects on larval red abalone Haliotis rufescens. Environ. Toxicol. Chem. 15:1245-1250.

Couper, J. M. \& E. M. Leise. 1996. Serotonin injections induce metamorphosis in larvae of the gastropod mollusc Ilyanassa obsoleta. Biol. Bull. 191:178-186.

Crim, R. N., J. M. Sunday \& C. D. G. Harley. 2011. Elevated seawater $\mathrm{CO}_{2}$ concentrations impair larval development and reduce larval survival in endangered northern abalone (Haliotis kamtschatkana). J. Exp. Mar. Biol. Ecol. 400:272-277.

Daume, S., A. Krsinich, S. Farrell \& M. Gervis. 2000. Settlement, early growth and survival of Haliotis rubra in response to different algal species. J. Appl. Phycol. 12:479-488.

Daume, S. \& S. Ryan. 2004. Nursery culture of the abalone Haliotis laevigata: larval settlement and juvenile production using cultured algae or formulated feed. J. Shellfish Res. 23:1019-1026.

Delgado, G. A., R. A. Glazer \& D. Wetzel. 2013. Effects of mosquito control pesticides on competent Queen Conch (Strombus gigas) larvae. Biol. Bull. 225:79-84.

Diederich, C. M., J. N. Jarrett, O. R. Chaparro, C. J. Segura, S. M. Arellano \& J. A. Pechenik. 2011. Low salinity stress experienced by larvae does not affect post-metamorphic growth or survival in three calyptraeid gastropods. J. Exp. Mar. Biol. Ecol. 397:94-106.

Dobberteen, R. A. \& J. A. Pechenik. 1987. Comparison of larval bioenergetics of two marine gastropods with widely differing lengths 
of planktonic life, Thais haemastoma canaliculata (Gray) and Crepidula fornicata (L.). J. Exp. Mar. Biol. Ecol. 109:173-191.

Eyster, L. S. \& J. A. Pechenik. 1988. Comparison of growth, respiration, and feeding of juvenile Crepidula fornicata (L.) following natural or KCl-triggered metamorphosis. J. Exp. Mar. Biol. Ecol. 118:269279.

Fukazawa, H., H. Takami, T. Kawamura \& Y. Watanabe. 2005. The effect of egg quality on larval period and postlarval survival of an abalone Haliotis discus hannai. J. Shellfish Res. 24:1141-1147.

Garcia Santaella, E. \& D. A. Aranda. 1994. Effects of algal food and feeding schedule on larval growth and survival rates of the queen conch, Strombus gigas (Mollusca, Gastropoda), in Mexico. Aquaculture 128:261-268.

Gaudette, M. F., J. L. Lowther \& J. A. Pechenik. 2001. Heat shock induces metamorphosis in the larvae of the prosobranch gastropod Crepidula fornicata. J. Exp. Mar. Biol. Ecol. 266:151-164.

Grubert, M. A. \& A. J. Ritar. 2004. The effect of temperature on the embryonic and larval development of blacklip (Haliotis rubra) and greenlip (H. laevigata) abalone. Invertebr. Reprod. Dev. 45:197-203.

Grudemo, J. \& C. André. 2001. Salinity dependence in the marine mud snails Hydrobia ulvae and Hydrobia ventrosa. J. Mar. Biol. Assoc. U.K. 81:651-654.

Hamel, J. \& A. Mercier. 2006. Factors regulating the breeding and foraging activity of a tropical opisthobranch. Hydrobiologia 571:225-236.

Hamel, J., P. Sargent \& A. Mercier. 2008. Diet, reproduction, settlement and growth of Palio dubia (Nudibranchia: Polyceridae) in the northwest Atlantic. J. Mar. Biol. Assoc. U.K. 88:365-374.

Hansen, B. \& K. W. Ockelmann. 1991. Feeding behaviour in larvae of the opisthobranch Philine aperta $\mathrm{I}$. Growth and functional response at different developmental stages. Mar. Biol. 111:255-261.

Hayimad, T., A. B. Abol-Munafi \& C. Pitagsalee. 2008. Effect of different diets on the growth and survival of the larvae and juveniles of spotted babylon snails (Babylonia areolata Link 1807). J. Sustain. Sci. Manag. 3:58-65.

Hunt, J. W. \& B. S. Anderson. 1989. Sublethal effects of zinc and municipal effluents on larvae of the red abalone Haliotis rufescens. Mar. Biol. 101:545-552.

Jackson, D. J., N. Ellemor \& B. M. Degnan. 2005. Correlating gene expression with larval competence, and the effect of age and parentage on metamorphosis in the tropical abalone Haliotis asinina. Mar. Biol. 147:681-697.

Jaeckle, W. B. \& D. T. Manahan. 1992. Experimental manipulations of the organic composition of seawater: implications for studies of energy budgets in marine invertebrate larvae. J. Exp. Mar. Biol. Ecol. 156:273-284.

Kang, K. H., B. Kim, J. M. Kim \& Y. H. Kim. 2003. Effects of amino acids on larval settlement and metamorphosis in Haliotis discus hannai. Korean J. Malacol. 19:95-106.

Kay, M. C. 2002. Recruitment in the intertidal limpet Lottia digitalis (Patellogastropoda: Lottiidae) may be driven by settlement cues associated with adult habitat. Mar. Biol. 141:467-477.

Klinzing, M. S. E. \& J. A. Pechenik. 2000. Evaluating whether velar lobe size indicates food limitation among larvae of the marine gastropod Crepidula fornicata. J. Exp. Mar. Biol. Ecol. 252:255-279.

Kritsanapuntu, S., N. Chaitanawisuti \& Y. Natsukari. 2007. Effects of different diet and seawater systems on egg production and quality of the broodstock Babylonia areolata L. under hatchery conditions. Aquacult. Res. 38:1311-1316.

Krug, P. J., D. Gordon \& M. R. Romero. 2012. Seasonal polyphenism in larval type: rearing environment influences the development mode expressed by adults in the sea slug Alderia willowi. Integr. Comp. Biol. 52:161-172.

Leise, E. M., S. J. Froggett, J. E. Nearhoof \& L. B. Cahoon. 2009. Diatom cultures exhibit differential effects on larval metamorphosis in the marine gastropod Ilyanassa obsoleta (Say). J. Exp. Mar. Biol. Ecol. 379:51-59.
Li, A. \& J. M. Y. Chiu. 2013. Latent effects of hypoxia on the gastropod Crepidula onyx. Mar. Ecol. Prog. Ser. 480:145-154.

Lima, G. M. \& J. A. Pechenik. 1985. The influence of temperature on growth rate and length of larval life of the gastropod, Crepidula plana Say. J. Exp. Mar. Biol. Ecol. 90:55-71.

Lin, K. J., T. P. Chen, T. S. Huang \& W. S. Tsai. 2004. Induced spawning and embryonic development of the top shell, Tectus pyramis. J. Taiwan Fish. Res, 12:49-60.

Liu, L., L. Chu \& K. Chang. 1986. Negative effect of $\gamma$-aminobutyric acid (GABA) on the settlement of larvae of the small abalone, Haliotis diversicolor supertexta Lischke. Bull. Inst. Zool. Acad. Sin. 25:1-5.

Lu, J. Y., Q. Lin, Y. Y. Sun, J. Q. Sheng \& Q. X. Chen. 2004. Effect of temperature on the early development of Haliotis diversicolor Reeve. J. Shellfish Res. 23:963-966.

Lucas, J. S. \& J. D. Costlow. 1979. Effects of various temperature cycles on the larval development of the gastropod mollusc Crepidula fornicata. Mar. Biol. 51:111-117.

Maldonado, R., A. M. Ibarra, J. L. Ramírez, S. Avila, J. E. Vázquez \& L. M. Badillo. 2001. Induction of triploidy in pacific red abalone (Haliotis rufescens). J. Shellfish Res. 20:1071-1075.

Manzano, B. N., D. A. Aranda \& E. B. Cárdenas. 1999. Development, growth and survival of larvae of the fighting conch Strombus pugilis L. (Mollusca, Gastropoda) in the laboratory. Bull. Mar. Sci. 64:201208.

Marty, R., N. Desroy, S. Bureau \& C. Retière. 2003. Relationship between density and feeding frequency for reared larvae of the gastropod Crepidula fornicata. J. Mar. Biol. Assoc. U.K. 83:499-500.

McGee, B. L. \& N. M. Targett. 1989. Larval habitat selection in Crepidula (L.) and its effect on adult distribution patterns. J. Exp. Mar. Biol. Ecol. 131:195-214.

Mestre, N. C., A. Brown \& S. Thatje. 2013. Temperature and pressure tolerance of larvae of Crepidula fornicata suggest thermal limitation of bathymetric range. Mar. Biol. 160:743-750.

Miller, S. E. \& M. G. Hadfield. 1986. Ontogeny of phototaxis and metamorphic competence in larvae of the nudibranch Phestilla sibogae Bergh (Gastropoda: Opisthobranchia). J. Exp. Mar. Biol. Ecol. 97:95-112.

Morse, D. E., H. Duncan, N. Hooker, A. Baloun \& G. Young. 1980. GABA induces behavioral and developmental metamorphosis in planktonic molluscan larvae. Fed. Proc. 39:3237-3241.

Noble, W. J., K. Benkendorff \& J. O. Harris. 2015. Growth, settlement and survival of Dicathais orbita (Neogastropoda, Mollusca) larvae in response to temperature, diet and settlement cues. Aquacult. Res. 46:1455-1468.

Padilla, D. K., M. J. McCann, M. McCarty Glenn, A. P. Hooks \& S. E. Shumway. 2014. Effect of food on metamorphic competence in the model system Crepidula fornicata. Biol. Bull. 227:242-251.

Park, C., Q. Li, T. Kobayashi \& A. Kijima. 2006. Inbreeding depression traits in Pacific abalone Haliotis discus hannai by factorial mating experiments. Fish. Sci. 72:774-780.

Pechenik, J. A. 1980. Growth and energy balance during the larval lives of three prosobranch gastropods. J. Exp. Mar. Biol. Ecol. 44:1-28.

Pechenik, J. A. 1984. The relationship between temperature, growth rate, and duration of planktonic life for larvae of the gastropod Crepidula fornicata (L.). J. Exp. Mar. Biol. Ecol. 14:241-257.

Pechenik, J. A., D. E. Cochrane, W. Li, E. T. West, A. Pires \& M. Leppo. 2007. Nitric oxide inhibits metamorphosis in larvae of Crepidula fornicata, the slippershell snail. Biol. Bull. 213:160-171.

Pechenik, J. A. \& L. S. Ester. 1989. Influence of delayed metamorphosis on the growth and metabolism of young Crepidula fornicata (Gastropoda) juveniles. Biol. Bull. 176:14-24.

Pechenik, J. A., M. S. Estrella \& K. Hammer. 1996a. Food limitation stimulates metamorphosis of competent larvae and alters postmetamorphic growth rate in the marine prosobranch gastropod Crepidula fornicata. Mar. Biol. 127:267-275. 
Pechenik, J. A. \& C. C. Gee. 1993. Onset of metamorphic competence in larvae of the gastropod Crepidula fornicata (L.), judged by a natural and artificial cue. J. Exp. Mar. Biol. Ecol. 167:59-72.

Pechenik, J. A., T. Gleason, D. Daniels \& D. Champlin. 2001. Influence of larval exposure to salinity and cadmium stress on juvenile performance of two marine invertebrates (Capitella sp. I and Crepidula fornicata). J. Exp. Mar. Biol. Ecol. 264:101-114.

Pechenik, J. A., K. Hammer \& C. Weise. 1996b. The effect of starvation on acquisition of competence and post-metamorphic performance in the marine prosobranch gastropod Crepidula fornicata (L.). J. Exp. Mar. Biol. Ecol. 199:137-152.

Pechenik, J. A. \& W. D. Heyman. 1987. Using KCI to determine size at competence for larvae of the marine gastropod Crepidula fornicata (L.). J. Exp. Mar. Biol. Ecol. 112:27-38.

Pechenik, J. A., T. J. Hilbish, L. S. Eyster \& D. Marshall. 1996c. Relationship between larval and juvenile growth rates in two marine gastropods, Crepidula plana and Crepidula fornicata. Mar. Biol. 125:119-127.

Pechenik, J. A., J. N. Jarrett \& J. Rooney. 2002a. Relationships between larval nutritional experience, larval growth rates, juvenile growth rates, and juvenile feeding rates in the prosobranch gastropod Crepidula fornicata. J. Exp. Mar. Biol. Ecol. 280:63-78.

Pechenik, J. A. \& S. H. Levine. 2007. Estimates of planktonic larval mortality using the marine gastropods Crepidula fornicata and Crepidula plana. Mar. Ecol. Prog. Ser. 344:107-118.

Pechenik, J. A. \& G. M. Lima. 1984. Relationship between growth, differentiation, and length of larval life for individually reared larvae of the marine gastropod, Crepidula fornicata. Biol. Bull. 166:537549.

Pechenik, J. A. \& A. S. Tyrell. 2015. Larval diet alters larval growth rates and post-metamorphic performance in the marine gastropod Crepidula fornicata. Mar. Biol. 162:1597-1610.

Pechenik, J. A., L. Wei \& D. E. Cochrane. 2002b. Timing is everything: the effects of putative dopamine antagonists on metamorphosis vary with larval age and experimental duration in the prosobranch gastropod Crepidula fornicata. Biol. Bull. 202:137-147.

Pena, J. B. 1985. The culture of Haliotis discus Reeve (Gastropoda; Prosobranchia) from fertilization to one-year-old in laboratory conditions. Iberus 5:21-30.

Penniman, J. R., M. K. Doll \& A. Pires. 2013. Neural correlates of settlement in veliger larvae of the gastropod, Crepidula fornicata. Invertebr. Biol. 132:14-26.

Pereira, L., J. Lagos \& F. Araya. 2007. Evaluation of three methods for transporting larvae of the red abalone Haliotis rufescens Swainson for use in remote settlement. J. Shellfish Res. 26:777-781.

Perron, F. E. 1981. Larval growth and metamorphosis of Conus (Gastropoda: Toxoglossa) in Hawaii. Pac. Sci. 35:25-38.

Phillips, N. E. 2011. Where are larvae of the vermetid gastropod Dendropoma maximum on the continuum of larval nutritional strategies? Mar. Biol. 158:2335-2342.

Pilkington, M. C. \& J. B. Pilkington. 1984. The stimulus for metamorphosis of a high-shore pulmonate, Amphibola crenata. J. R. Soc. N. Z. 14:139-143.

Pillsbury, K. S. 1985. The relative food value and biochemical composition of five phytoplankton diets for queen conch, Strombus gigas (Linne) larvae. J. Exp. Mar. Biol. Ecol. 90:221-231.

Pires, A. \& M. G. Hadfield. 1991. Oxidative breakdown products of catecholamines and hydrogen peroxide induce partial metamorphosis in the nudibranch Phestilla sibogae Bergh (Gastropoda: Opisthobranchia). Biol. Bull. 180:310-317.

Pires, A. \& M. G. Hadfield. 1993. Responses of isolated vela of nudibranch larvae to inducers of metamorphosis. J. Exp. Zool. 266:234-239.

Raimondi, P. T., A. M. Barnett \& P. R. Krause. 1997. The effects of drilling muds on marine invertebrate larvae and adults. Environ. Toxicol. Chem. 6:1218-1228.
Richmond, C. E. \& S. A. Woodin. 1999. Effect of salinity reduction on oxygen consumption by larval estuarine invertebrates. Mar. Biol. $134: 259-267$.

Roberts, R. D., H. F. Kaspar \& R. J. Barker. 2004. Settlement of abalone (Haliotis iris) larvae in response to five species of coralline algae. J. Shellfish Res. 23:975-987.

Roberts, R. D., T. Kawamura \& C. M. Handley. 2007. Factors affecting settlement of abalone (Haliotis iris) larvae on benthic diatoms films. J. Shellfish Res. 26:323-334.

Roberts, R. D., T. Kawamura \& C. M. Nicholson. 1999. Growth and survival of postlarval abalone (Haliotis iris) in relation to development and diatom diet. J. Shellfish Res. 18:243-250.

Roberts, R. D., C. Lapworth \& R. J. Barker. 2001. Effect of starvation on the growth and survival of post-larval abalone (Haliotis iris). Aquaculture 200:323-338.

Roberts, R. D. \& C. M. Nicholson. 1997. Variable response from abalone larvae (Haliotis iris, $H$. virginea) to a range of settlement cues. Molluscan Res. 18:131-141.

Roberts, R. D. \& E. Watts. 2010. Settlement of Haliotis australis larvae: role of cues and orientation of the substratum. J. Shellfish Res. 29:663-670.

Rodriguez, S. R., C. Riquelme, E. O. Campos, P. Chavez, E. Brandan \& N. C. Inestrosa. 1995. Behavioral responses of Concholepas concholepas (Bruguière, 1798) larvae to natural and artificial settlement cues and microbial films. Biol. Bull. 189:272-279.

Romero, M. R., K. M. Walker, C. J. Cortez, Y. Sanchez, K. J. Nelson, D. C. Ortega, S. L. Smick, W. J. Hoese \& D. C. Zacherl. 2012. Larval diel vertical migration of the marine gastropod Kelletia kelletii (Forbes, 1850). J. Mar. Biol. 2012:1-9.

Santaella, E. G. \& D. A. Aranda. 1994. Effect of algal food and feeding schedule on larval growth and survival rates of the queen conch, Strombus gigas (Mollusca, Gastropoda), in Mexico. Aquaculture 128:261-268.

Sawatpeera, S., M. Kruatrachue, P. Sonchaeng, S. Upatham \& T. Rojanasarampkit. 2004. Settlement and early growth of abalone larvae Haliotis asinine Linnaeus in response to presence of diatoms. Veliger 47:91-99.

Schlesinger, A., R. Goldshmid, M. G. Hadfield, E. Kramarsky-Winter \& Y. Loya. 2009. Laboratory culture of the aeolid nudibranch Spurilla neopolitana (Mollusca, Opisthobranchia): life history aspects. Mar. Biol. 156:753-761.

Searcy-Bernal, R. \& C. Anguiano-Beltrán. 1998. Optimizing the concentration of gamma-aminobutyric acid (GABA) for inducing larval metamorphosis in the red abalone Haliotis rufescens (Mollusca: Gastropoda). J. World Aquacult. Soc. 29:463-470.

Searcy-Bernal, R., A. E. Salas-Garza, R. A. Flores-Aguilar \& P. R. Hinojosa-Rivera. 1992. Simultaneous comparison of methods for settlement and metamorphosis induction in the red abalone ( $\mathrm{Hal}$ iotis rufescens). Aquaculture 105:241-250.

Seelemann, U. 1967. Rearing experiments on the amphibian slug Alderia modesta. Helgoland. Wiss. Meer. 15:128-134.

Shaojun, B., Z. Tao, P. Hengqian, P. Yang, W. Pingchuan \& X. Dongxiu. 2014. Effects of temperature and salinity on the development of embryos and larvae of the veined rapa whelk Rapana venosa (Valenciennes, 1846). Chin. J. Oceanology Limnol. 32:773-782.

Shen, Y. L., J. T. Huang, X. P. Ge, A. M. Wang, F. Lv, W. C. Cai \& N. N. Shen. 2013. Effects of different hatching ways, cultivating densities and incubators on the artificial breeding of Onchidium struma. Mar. Sci. 37:109-116.

Shieh, H. \& L. Liu. 1999. Positive effects of large concentration in culture on the development of the lecithotrophic larvae of Babylonia formosae (Sowerby) (Prosobranchia: Buccinidae). J. Exp. Mar. Biol. Ecol. 241:97-105.

Sisson, C. D. 2002. Dichotomous life history patterns for the nudibranch Dendronotus frondosus (Ascanius, 1774) in the Gulf of Maine. Veliger 45:290-298. 
Slattery, M. 1992. Larval settlement and juvenile survival in the red abalone (Haliotis rufescens) - an examination of inductive cues and substrate selection. Aquaculture 102:143-153.

Stoner, A. W., M. Ray, R. A. Glazer \& K. J. McCarthy. 1996. Metamorphic responses to natural substrata in a gastropod larva: decisions related to postlarval growth and habitat preference. J. Exp. Mar. Biol. Ecol. 205:229-243.

Stott, A. E., T. Takeuchi \& Y. Koike. 2004. An alternative culture system for the hatchery production of abalone without using livefood. Aquaculture 236:341-360.

Struhsaker, J. W. \& J. D. Costlow. 1969. Some environmental effects on the larval development of Littorina picta (Mesogastropoda), reared in the laboratory. Malacologia 9:403-419.

Taris, N., T. Comtet, R. Stolba, R. Lasbleiz, J. A. Pechenik \& R. Viard. 2010. Experimental induction of larval metamorphosis by a naturally-produced halogenated compound (dibromomethane) in the invasive mollusc Crepidula fornicata (L.). J. Exp. Mar. Biol. Ecol. 393:71-77.

Teng, W., X. Wu, B. Tang, Y. Cheng, B. Zhou, J. Wang, J. Wang \& Y. Chen. 2007. The study of ecological reproduction of Onchidium struma in wetland. Mar. Fish. 29:1004-2490.

Todd, C. D., M. G. Bentley \& J. N. Havenhand. 1991. Larval metamorphosis of the opisthobranch mollusc Adalaria proxima (Gastropoda: Nudibranchia): the effects of choline and elevated potassium ion concentration. J. Mar. Biol. 71:53-72.

Trowbridge, C. D. 1998. Stenophagous, herbivorous sea slugs attack desiccation-prone, green algal hosts (Codium spp.): indirect evidence of prey-stress models (PSMs)? J. Exp. Mar. Biol. Ecol. 230:31-53.

Untersee, S. \& J. A. Pechenik. 2007. Local adaptation and maternal effects in two species of marine gastropod (genus Crepidula) that differ in dispersal potential. Mar. Ecol. Prog. Ser. 347:79-85.
Ushakova, O. O. \& O. L. Saranchova. 2003. Low salinity resistance of plankton larvae in invertebrates (Polychaeta, Gastropoda, Echinodermata, and Bryozoa) from the White Sea. Zool. Zh. 82:318-324.

Vargas, C. A., M. De la Hoz, V. Aguilera, V. San Martín, P. H. Manríquez, J. M. Navarro, R. Torres, M. A. Lardies \& N. A. Lagos. 2013. $\mathrm{CO}_{2}$ - driven ocean acidification reduces larval feeding efficiency and changes food selectivity in the mollusk Concholepas concholepas. J. Plankton Res. 35:1059-1068.

Vargas, C. A., P. H. Manriquez \& S. A. Navarrete. 2006. Feeding by larvae of intertidal invertebrates: assessing their position in pelagic food webs. Ecology 87:444 457.

Yang, Z., X. Zhang \& Z. Cai. 2009. Toxic effects of several phthalate esters on the embryos and larvae of abalone Haliotis diversicolor supertexta. Chin. J. Oceanology Limnol. 27:395-399.

Yaroslawseva, L. M. \& E. P. Sergeeva. 2008. Adaptive abilities of marine invertebrate larvae under changes in environmental factors as sensitive test for sea water pollution. Biologiia Moria 34:42-46.

Zhao, B., J. Qiu \& P. Qian. 2003. Effects of food availability on larval development in the slipper limpet Crepidula onyx (Sowerby). J. Exp. Mar. Biol. Ecol. 294:219-233.

Zheng, H., C. Ke, S. Zhou \& F. Li. 2005. Effects of starvation on larval growth, survival and metamorphosis of ivory shell Babylonia formosae habei Altena et al., 1981 (Neogastropoda: Buccinidae). Aquaculture 243:357-366.

Zimmerman, K. M. \& J. A. Pechenik. 1991. How do temperature and salinity affect relative rates of growth, morphological differentiation, and time to metamorphic competence in larvae of the marine gastropod Crepidula plana? Biol. Bull. 180:372-386.

Zippay, M. L. \& G. E. Hoffman. 2010. Effect of $\mathrm{pH}$ on gene expression and thermal tolerance of early life history stages of red abalone (Haliotis rufescens). J. Shellfish Res. 29:429-439. 